
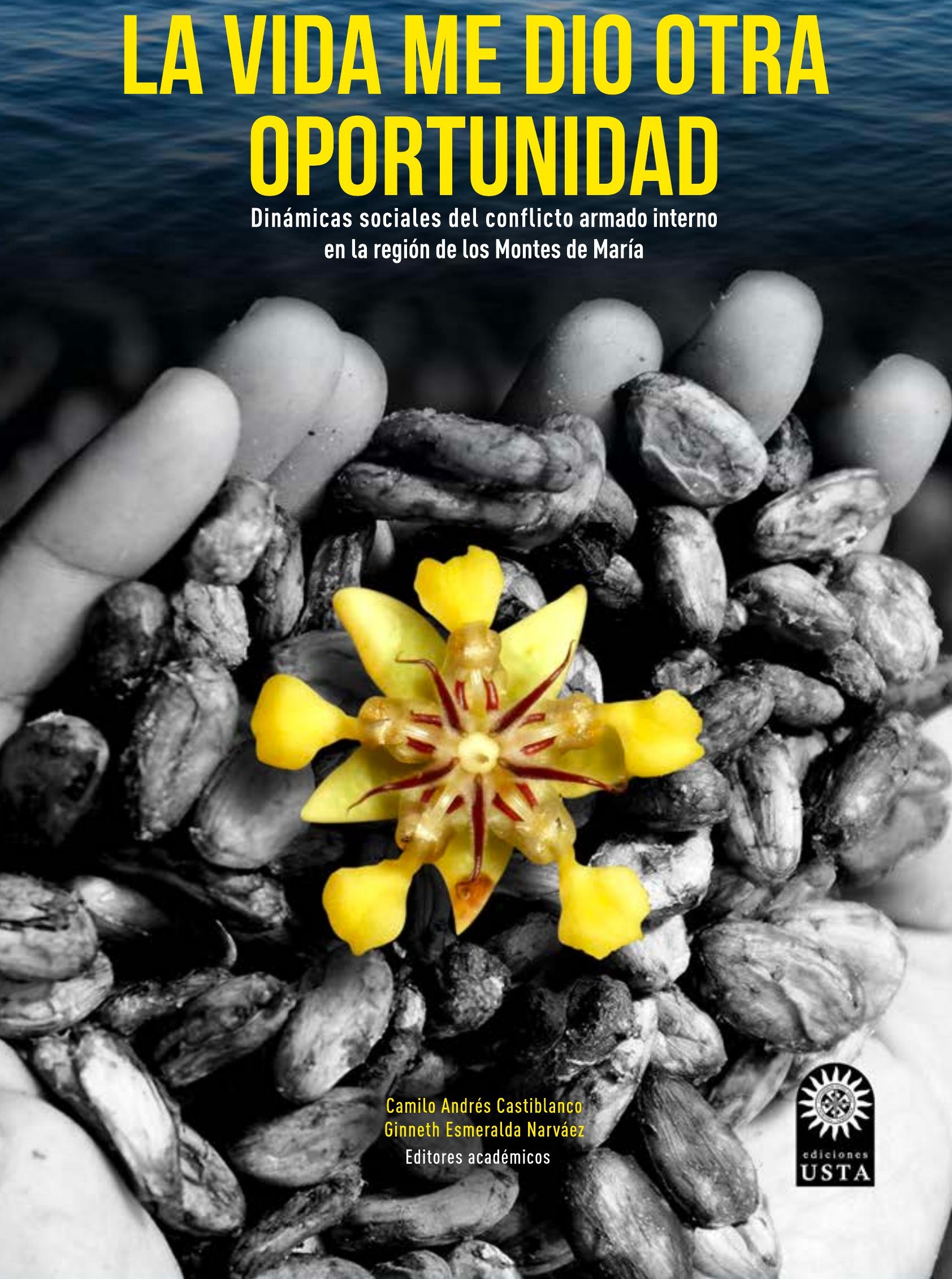




\section{La vida me dio otra oportunidad}

Dinámicas sociales del conflicto armado interno en la región de los Montes de María 



\section{La vida me dio otra oportunidad \\ Dinámicas sociales del conflicto armado interno en la región de los Montes de María}

Camilo Andrés Castiblanco

Ginneth Esmeralda Narváez Jaimes

-Editores académicos-

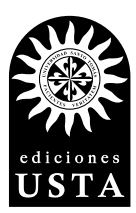


Garzón Moreno, Daniel

La vida me dio otra oportunidad. Dinámicas sociales del conflicto armado en la región de Montes de María/Daniel Garzón Moreno (y otros cinco), Editores académicos: Camilo Andrés Castiblanco y Ginneth Esmeralda Narváez Jaimes / Bogotá: Universidad Santo Tomás, 2018.

358 páginas; gráficos, imágenes a color, mapas, tablas

Incluye referencias bibliográficas

ISBN 978-958-782-111-6

E-ISBN: 978-958-782-112-3

Conflicto Armado 2. Desplazados por la violencia 3. Crímenes contra niños-Violencia infantil 4. Investigaciones en violencia 5 Violencia rural - Colombia 6. Víctimas de la violenciaMontes de María (Región, Colombia) I. Universidad Santo Tomás (Colombia).

CDD 303.6 CO-BoUST

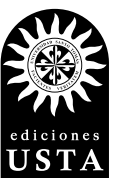

(C) Daniel Garzón Moreno, John Valencia Riaño, Ginneth Esmeralda Narváez Jaimes, María del Mar Martínez, Camilo Andrés Castiblanco, Carol Malaver Sánchez, Edward Salazar, Francisco Parra, Sady del Valle, Germán Romero, María Antonia Alfonzo.

Editores académicos: Camilo Andrés Castiblanco y Ginneth Esmeralda Narváez Jaimes. Auxiliares de investigación: Daniela Maldonado Palacios, Camila Sánchez Pulido, Cristóbal Sierra Ucros, Iván Ramírez.

(C) Universidad Santo Tomás, 2018

(C) Armada Nacional de Colombia, 2018

Ediciones USTA Carrera 9 n. ${ }^{\circ}$ 51-11

Bogotá, D. C., Colombia

Teléfono: (+571) 5878797 ext. 2991

editorial@usantotomas.edu.co

http://www.ediciones.usta.edu.co

Coordinación de libros: Karen Grisales Velosa

Corrección de estilo: Ludwing Cepeda Aparicio

Diagramación: Diseño M'Enciso

Diseño de cubierta: David Ríos

Crédito fotográfico: Armada Nacional de Colombia y Universidad Santo Tomás

Hecho el depósito que establece la ley

ISBN: 978-958-782-111-6

E-ISBN: 978-958-782-024-9112-3

Impreso en Colombia - Printed in Colombia

Impreso por: Xpress Estudio Gráfico y Digital S. A. S.

Primera edición, 2018

Todos los derechos reservados.

Se prohíbe la reproducción total o parcial de esta obra, por cualquier medio, sin la autorización previa por escrito del titular de los derechos. 


\section{Tabla de contenido}

$\begin{array}{ll}\text { Agradecimientos } & 15\end{array}$

$\begin{array}{ll}\text { Introducción } & 17\end{array}$

Palabras de inicio $\quad 23$

$\begin{array}{ll}\text { Presentación } & 25\end{array}$

Capítulo 1. Configuración histórica y causas

de la violencia en la región de Montes de María 27

$\begin{array}{ll}\text { Introducción } & 29\end{array}$

Configuración histórica y económica
de la subregión de los Montes de María 1850-1998

Las actividades económicas de finales del siglo xx

transformadas por el nuevo modelo económico

y la consolidación de los grupos armados ilegales $\quad 45$

$\begin{array}{ll}\text { Impactos y dinámicas socioculturales } & \\ \text { en los Montes de María } & 60\end{array}$

La Armada Nacional en los Montes de María:

una intervención para el fortalecimiento

económico y social de la región $\quad 76$

$\begin{array}{ll}\text { Referencias } & 82\end{array}$

Capítulo 2. Dinámicas de la violencia

en Montes de María (1970-2010) 87

Perspectiva histórica 90

$\begin{array}{ll}\text { Contexto nacional } & 92\end{array}$ 
Ejército Popular de Liberación (EPL) 100

Ejército de Liberación Nacional (ELN) 106

Ejército Revolucionario del Pueblo (ERP) 112

Fuerzas Armadas Revolucionarias de Colombia -

Ejército del Pueblo (FARC-EP) 114

Autodefensas Unidas de Colombia (AUC) 135

Modelos y métodos de guerra revolucionaria

en Montes de María (FARC, ELN y EPL) 143

Las dinámicas del conflicto: luchas territoriales

y disputas entre actores armados

Desarrollo y éxito operacional

de la armada en los Montes de María $\quad 169$

Conclusiones 174

$\begin{array}{ll}\text { Referencias } & 177\end{array}$

Capítulo 3. Cinco masacres ocurridas

en la región: contexto jurídico $\quad 183$

Pichilín: 4 de diciembre de $1996 \quad 194$

Capaca: 16 de agosto de $1999 \quad 203$

El Salado: 16 al 21 de febrero de $2000 \quad 208$

Mampuján: 10 de marzo de $2000 \quad 219$

Chengue: 17 de enero de $2001 \quad 225$

Apuntes de cierre para la comprensión de los casos 235

Referencias $\quad 240$

Capítulo 4. Las víctimas de la región

de Montes de María 243

Introducción $\quad 245$

Las dinámicas de la victimización en la región

de Montes de María. Un abordaje desde las cifras

y las estadísticas

246

Las memorias de la violencia $\quad 256$

Territorialización de la violencia $\quad 259$

El estigma y la soledad de Montes de María $\quad 282$

El legado de la guerra $\quad 284$

$\begin{array}{ll}\text { Recuperando la montaña } & 288\end{array}$

Arte y cultura, la cura de los Montes heridos 291

$\begin{array}{ll}\text { Referencias } & 294\end{array}$ 
Capítulo 5. Crónicas de víctimas

297

Crónica 1. "Muchos transportadores vieron

a su empresa consumirse entre las llamas"

299

Crónica 2. El pueblo candado

301

Crónica 3. "Así como cargaba mi mochila,

así cargaba la muerte a cuestas"

306

Crónica 4. El Salado, el pueblo que se partió en dos

311

Crónica 5. "La guerrilla nos trató de envenenar"

318

Crónica 6. El dolor de perder la tierrita

320

Crónica 7. "Mi hijo nació en el monte"

324

Crónica 8. "En mi pueblo la guerrilla

desahuciaba a la policía"

330

Crónica 9. “Nosotros no somos partidarios de ningún tipo de causa, solo queríamos un mejor pueblo"

Crónica 10. "Fui violada por varios hombres a la vez"

Crónica 11. “Dios mío, yo sé que estoy mocho, pero déjame vivir"

Crónica 12. La Casa del Almirante: el buen amigo 



\section{Índice de figuras}

Figura I-1: Aspectos sociales y agrícolas en la subregión de los Montes de María

Figura I-2: Exportaciones colombianas de tabaco a Bremen, lugar de origen y volumen total, 1856-1871 (en zurrones) 41

Figura I-3: Producción de Tabaco en el Municipio de Ovejas 42

Figura 1-4: Movilización de la Asociación

Nacional de Usuarios Campesinos (ANUC) 44

Figura 1-5: Evolución del conflicto armado (1990-2002);

acciones guerrilleras más recurrentes (1990-2010)

Figura I-6: Área sembrada y cosechada en Zodes, Montes de María, Bolívar 2000-2010

Figura 1-7: Estructura agrícola, departamento de Bolívar

Figura I-8: Estructura agrícola, departamento de Sucre

Figura II-1: Presencia del ELN en Montes de María

Figura II-2: Presencia del ERP en Montes de María

Figura II-3: Presencia Frente 35 FARC, en Montes de María

Figura II-4: Presencia Frente 37 FARC, en Montes de María

Figura II-5: Hombres en armas FARC 2002- 2012

Figura II-6: Presencia Auc en Montes de María

Figura II-7: Incursión de guerrillas de primera generación, Montes de María

Figura II-8: Combates de la Fuerza Pública contra grupos armados irregulares 
Figura II-9: Evolución de la insurgencia y las autodefensas ilegales 1999-2009, en la región de los Montes de María 149

Figura II-10: Proporción homicidios por municipio 2002-2005 151

Figura II-11: Tasas de homicidio nacional de la región Montes de María y del resto de municipios de Sucre. Comparativo

Figura II-12: Tasas de homicidio por subregión comparado con el promedio nacional 2003-2006 153

Figura II-13: Desplazamiento forzado (1997-2005) 158

Figura II-14: Número total de masacres en la región de los Montes de María (1995-2005)

Figura II-15: Víctimas de minas antipersonal en Montes de María (2002-2009)

Figura II-16: Número total de ataques terroristas en al región de los Montes de María (1993-2005)

Figura II-17: Estadística de la reducción de los delitos motivados por la insurgencia dentro de la región de Montes de María (2003-2010)

Figura III-1: Dispositivo Unidades Primera Brigada

e Infantería de Marina

Figura IV-1: Relación de tipo de delitos por municipio 247

Figura IV-2: Acciones violentas por categoría (1985-2014) 250

Figura IV-3. El resistente $\quad 256$

Figura IV-4. El silencio $\quad 282$

Figura IV-5. Memorias $\quad 284$

Figura IV-6. Vigilia $\quad 288$

Figura IV-7. La Gaita $\quad 291$ 


\section{Índice de tablas}

Tabla I-1: Solicitudes de restitución de tierras por municipio de los Montes de María

Tabla II-1: Contraste demandas y compromisos logrados

entre Gobierno colombiano y guerrilla (1991)

Tabla II-2: Periodos de desarrollo del conflicto armado en el Caribe colombiano

Tabla II-3: Operaciones exitosas de la Armada Nacional contra la guerrilla

Montes de María (2004-2009)

Tabla II-4: Desmovilizaciones colectivas. Bloques AUC (2003-2006) 140

Tabla II-5: Modelos, estructura político-militar y fundamentos de guerra revolucionaria

Tabla II-6: Indicadores de impacto de conflicto en población de María 2003-2009

Tabla II-7: Homicidios por municipio en los Montes de María (2003-2009)

Tabla II-8: Desplazamiento forzado (por expulsión) en los Montes de María comparado con el total de los departamentos de Sucre y Bolívar

Tabla II-g: Desplazamiento forzado (por expulsión) en los Montes de María 
Tabla II-10: Desplazados de Montes de María (1985-2018)

Tabla II-11: Desplazamiento de afrocolombianos

en los Montes de María (2003-2008)

Tabla II-12: Tácticas predominantes de los grupos armados ilegales 168

Tabla III-1. Estructura de la Primera Brigada de Infantería de Marina $\quad 189$

Tabla III-2. Acciones violentas realizadas por parte de las organizaciones ilegales

Tabla III-3. Estructura de los grupos de autodefensas ilegales Bloque Norte, Frente Rito Antonio Ochoa

Tabla IV-1. Número de hechos de conflicto armado

en los Montes de María perpetrados por la guerrilla (1988-2007)

Tabla IV-2: Acciones violentas desarrolladas por las FARC según año (1988-2007)

Tabla IV-3: Acciones violentas desarrolladas por las AUC 


\section{Agradecimientos}

Este libro es el resultado de un trabajo interinstitucional entre la Armada Nacional y la Universidad Santo Tomás; para su realización se contó con el apoyo de un gran número de personas, para todas ellas, de forma general, un sincero saludo de gratitud. El agradecimiento más especial es para la comunidad de los Montes de María, una población generosa que nos permitió acceder a sus historias y a sus vivencias; esperamos que esta publicación sea acorde con las memorias narradas, y que contribuya en el proceso de reparación.

La División de Ciencias Sociales de la Universidad Santo Tomás fue un apoyo permanente en el desarrollo del proyecto, por ello, un especial reconocimiento a los Padres Decanos de División que acompañaron y lideraron el proceso: Fray Esneider Claros Castro y Fray Ismael Leonardo Ballesteros Guerrero; así mismo, a la Decana de Diseño Gráfico: Piedad Gómez Castillo, quien acompañó y supervisó todo el proceso, y cuyo liderazgo fue fundamental para desarrollar sinergias entre las dos instituciones. Finalmente, un sincero agradecimiento al Decano de Sociología Miguel Urra Canales y a la Decana de Comunicación Social para la Paz María Ligia Herrera, apoyos académicos para todo el proceso.

Un especial agradecimiento para el señor Almirante John Fabio Giraldo Gallo -Jefe de la Jefatura Jurídica Integral-, quien fue un apoyo constante para esta publicación, generando la posibilidad de 
construir una articulación interinstitucional para el desarrollo de este libro; de igual manera, un sentimiento de gratitud para el Señor Capitán de Navío Juan Gabriel Rozo Torres, artífice de este proyecto, y quien lideró el convenio interinstitucional; la Capitán de Corbeta Margarita María Miranda Guerrero y la Teniente de Fragata María Antonia Alfonzo Mujica fueron los enclaves entre las dos instituciones, su participación y colaboración fue fundamental para el cierre exitoso de esta investigación. Por último, y no por eso menos importante, gracias al Contralmirante Andrés Vásquez Villegas, Jefe de la Jefatura de Formación, Instrucción y Educación Naval - a través de su grupo de investigación Poseidón, Categoría B, liderado por el Capitán de Fragata Fabián Ramírez Cabrales-, por la posibilidad de gestionar y compartir el proceso investigativo interinstitucional.

El equipo de investigación contó con el apoyo profesional de Daniela Maldonado Palacios, Camila Andrea Sánchez Pulido, Cristóbal Sierra Ucros e Iván Ramírez, quienes realizaron a cabalidad su trabajo y brindaron los insumos necesarios para el desarrollo del texto; sin ellos esta publicación no podría haberse llevado a cabo. 


\section{Introducción}

La región de los Montes de María ha estado en el debate público por la crueldad y la barbarie de las acciones irregulares cometidas por los grupos armados ilegales que allí tuvieron presencia; en el imaginario colectivo sobresalen episodios desgarradores como los acontecidos en el corregimiento del Salado, o por hechos que transgreden todas las convenciones internacionales sobre cómo desarrollar acciones bélicas en el marco de un conflicto armado interno, tal y como sucedió en Chalán. Pero al mismo tiempo, la región fue el escenario de un proceso de consolidación de la seguridad por parte de la Fuerza Pública, en particular por el despliegue realizado por la Armada Nacional, lo que se tradujo en transformaciones significativas de los indicadores de bienestar social y económico de la región. Esta situación evidencia la necesidad de tener una mirada histórica y compleja del territorio, en la que se dimensionen los distintos momentos históricos vividos y las transformaciones que se presentaron en todos los ámbitos.

La investigación centra su atención en el papel protagónico que desarrollo la Infantería de Marina en esta región, afrontando amenazas de seguridad complejas y cambiantes; para ello, hace uso de la estrategia metodológica de los contextos, en la que se analizan los factores endógenos y exógenos que fueron incidentes en las formas de violencia desarrolladas; y las distintas afectaciones que estas dinámicas del conflicto generaron sobre la población civil; al final, es 
evidente que el actuar de la Armada Nacional fue fundamental para detener la barbarie, pero también pone de presente que el triunfo en el terreno militar exigía de un proceso de acompañamiento y consolidación por parte de todas las instituciones del Estado, proceso que aún es incipiente e insuficiente para las necesidades de esta población.

Este abordaje epistemológico permite comprender los procesos económicos, culturales y políticos que devinieron en expresiones de violencia. Todos estos elementos, que son asumidos como posibles causas generadoras del conflicto y la violencia en la región, son analizados en el primer capítulo, un documento que permite que el lector se introduzca históricamente en la región, dimensionando los factores causantes de las diversas formas de violencia acontecidas. A su vez, el documento muestra cómo varios de estos factores generadores se transformaron tras la intervención del Estado a través de la Fuerza Pública.

Derivado de esta comprensión histórica, emerge un escenario complejo en el que hicieron presencia distintas estructuras armadas ilegales en la región; cada una de estas con diferentes estrategias, con móviles y objetivos particulares y con una relación particular con el territorio. De allí que sea necesario generar un proceso de esclarecimiento sobre las diferentes formas de afectación que cada uno de estos generó y sobre las relaciones de poder que llevaron a que las FARC (Frente 37 y Bloque 35) y las Auc (Bloque Héroes de Montes de María) obtuvieran una mayor capacidad de incidencia sobre el territorio.

Este análisis histórico de los grupos armados ilegales es fundamental para comprender las distintas lecturas que estos hicieron del territorio, las configuraciones de poder que alrededor de los mismos se tejieron y las rutas y tránsitos que el conflicto asumió por medio de sus luchas por el control de las subszonas de la región. El eje central de este análisis gira en torno a la naturaleza dinámica, histórica y, por ende, cambiante de los grupos ilegales; hablar de las FARC o de las AUC en la región es entender que cada una de estas organizaciones mutó y se transformó en función de diferentes fenómenos, lo que generó que las correlaciones de poder entre estos dos actores fluctuará permanentemente, y que por lo mismo se presentaron distintos procesos de disputa por el control ilegal de los municipios.

Esta naturaleza dinámica de los actores ilegales determinó y afectó la manera en la que el Estado enfrentó y contrarrestó dicha amenaza, ocasionando que la misma Fuerza Pública entrara en una 
necesidad permanente de valorar y transformar sus operaciones sobre el territorio. Uno de los mayores ejemplos de esta situación fue la presencia de la Armada Nacional, a través de la Infantería de Marina en la región; una institución que adaptó y transformó su misionalidad para asumir un contexto que era ajeno a su tradición. En ese sentido, se analiza el rol de la Armada Nacional en el territorio, con el mismo esquema metodológico que se viene empleando, esto es, con un enfoque histórico, comprendiendo distintos momentos operacionales desarrollados para asegurar el control de la zona.

Este análisis de las dinámicas de violencia en la región y del accionar de los grupos armados examina los elementos propios de la estrategia, la táctica de los diversos grupos ilegales, permite comprender que esto obedecía a un propósito como a unas apuestas cambiantes por el territorio; de esta manera, se podrá comprender en el terreno mismo de la guerra el porqué del uso del terror de la barbarie, como un repertorio válido para algunos de estos actores ilegales.

Esta mirada técnica del conflicto se engranará con un análisis cuantitativo y cualitativo de diversos tipos de víctimas de los Montes de María; en un primer momento, se analizarán las estadísticas (de diversas fuentes) sobre las consecuencias de las acciones violentas ocurridas en la región, dimensionado las zonas afectadas, los grupos sociales vulnerados y las lógicas mismas que se desprenden de la confrontación.

Esta revisión de las cifras disponibles es fundamental para estructurar un análisis cualitativo, en el que se humanizan los datos, y se le colocan rostros al terror y al sufrimiento que la población padeció durante estos años, pero en el que también se comprenden las distintas percepciones sobre los hechos que tiene la población. Un análisis cualitativo en el que se entrecruzarán enfoques analíticos de las ciencias sociales, con abordajes periodísticos (crónicas) en los que se afirman las formas particulares en las que distintos grupos sociales interactuaron con la violencia y las estrategias humanas desarrolladas para resistir y superar el dolor y la tragedia. Comprender el conflicto armado desde la sociedad, y en particular desde la población que se vio afectada por el conflicto, es un paso fundamental para estructurar

1 Algunas de ellas registradas en la UARIV (Unidad para la Atención y Reparación Integral a las Víctimas); otras en proceso del reconocimiento legal y político. 
una construcción de verdad sobre lo acontecido en la región, y sobre las reacciones de la población civil ante los hechos acontecidos; una memoria histórica plural en la que quepan distintas interpretaciones y visiones de la realidad.

La multiplicidad de percepciones de aquellos que se vieron afectados por el conflicto permite superar los análisis en los que la confrontación es analizada como una ecuación material en la que hay actores irregulares disputándose los recursos de un territorio, permitiendo que nuevos elementos analíticos complementen y complejicen el esclarecimiento mismo de lo sucedido, entendiendo, por supuesto, que son relatos y percepciones particulares y fragmentadas de la realidad, pero que cuando se ponen en sintonía reflejan elementos sucintos de análisis.

Uno de los intereses de la investigación fue la comprensión de distintos testimonios y narrativas de lo acontecido, empezando por la lectura institucional que la Armada Nacional hizo del territorio y de la amenaza que sobre este se cernía; así mismo, una revisión de los testimonios de los miembros de esta Institución que se vieron afectados por las acciones irregulares e inhumanas de los grupos armados ilegales, lo que permitió comprender desde una perspectiva humana las condiciones adversas en las que tuvo que operar la Infantería de Marina. A la par, se recogen testimonios de la población civil afectada, lo cual permite triangular posiciones y perspectivas, configurando una memoria integral e incluyente de lo que sucedió en los Montes de María.

Este libro complementa un trabajo investigativo desarrollado por la División de Ciencias Sociales de la Universidad Santo Tomás en asocio con la Dirección de Víctimas y Memoria Histórica de la Armada Nacional, de la cual ya se publicó un primer producto: el libro Protegiendo el azul, comprendí el rojo de la bandera, publicado en el 2017. En esta ocasión, se realizó un trabajo conjunto entre el grupo de investigación Conflicto, Género y Territorios de la Universidad Santo Tomás (Categoría B) con el grupo de investigación Poseidón de la Armada Nacional (Categoría B), liderado por el Capitán de Fragata Fabián Ramírez Cabrales. 
Esta iniciativa de trabajo conjunta entre las dos instituciones está caracterizada por distintos acuerdos que vale la pena hacer explícitos para el lector: en primer lugar, las dos entidades han salvaguardado la independencia y autonomía para la realización de esta investigación; esto es una condición de las dos partes para garantizar la calidad y veracidad de la información aquí contenida.

Un segundo elemento que vale la pena destacar tiene que ver con el compromiso de las dos instituciones por participar en los espacios académicos y políticos que afronta el país para esclarecer las causas y consecuencias del conflicto armado interno, en el marco de la estructuración de una memoria histórica plural e incluyente, que permita construir vasos comunicantes entre las partes.

Sin embargo, aunque hay un afán común por participar, sobresalen elementos diferenciales de las dos instituciones en este objetivo. La Armada Nacional está regida por el principio del Deber de Memoria (Ley 1448 de 2011), lo que le genera un compromiso ético con el país por esclarecer cuál fue su participación en el marco del conflicto armado, por ello en las últimas dos publicaciones se ha colocado de presente el contexto del conflicto armado, las afectaciones de la población civil en el marco de este contenido, y la necesidad de abordar metodológicamente un tema como el de los militares víctimas por el conflicto armado interno. En particular, la Armada Nacional ha mostrado un gran interés por aportar a la construcción de la memoria histórica a una de las regiones en donde su presencia y participación fue decisiva para el logro de la seguridad, pero donde también quedó en entredicho su actuación por presuntos comportamientos irregulares de algunos de sus miembros; motivo ético que la lleva a aportar al esclarecimiento de los acontecimientos.

La Universidad se inscribe en el marco de un esfuerzo y una responsabilidad académica por ser incidente en una de las coyunturas políticas e históricas más importantes del país en las últimas décadas: la posibilidad de transitar del posacuerdo al posconflicto tras la firma de los Acuerdos de Paz con las FARc. Para ello, se entiende la necesidad y preponderancia que tiene la Verdad - en términos de la justicia transicional-como herramienta que permite el esclarecimiento de los contextos, y la dignificación y reparación de las víctimas; pero también como insumo fundamental para que existan garantías de no repetición y voluntad de paz de las partes del conflicto. 
Un tercer y último elemento articulador de la relación interinstitucional tiene que ver con la mirada plural y comprensiva del fenómeno de las víctimas. En esta publicación se ponen en el mismo nivel la humanización a las víctimas civiles como a los miembros de la Armada Nacional y sus familias, afectados por el conflicto armado colombiano, entendiendo que las afectaciones son transversales a los grupos humanos y generan diversas cicatrices y heridas para la sociedad.

El resultado final es el reflejo del trabajo conjunto de las dos instituciones y coloca de presente la importancia de la articulación de la academia con las instituciones militares en el marco de la autonomía como una muestra de que la paz y la memoria es una responsabilidad de todos y que para alcanzar una verdad incluyente se necesita del trabajo conjunto. 


\section{Palabras de inicio}

Los Montes de María son una región que ha estado presente en el imaginario colectivo de los colombianos como una zona en la que predominó el conflicto armado, pero también como la tierra que evoca los ritmos del maestro Lucho Bermúdez y los sonidos de las gaitas; los cultivos de yuca, tabaco y aguacate; los manglares y las ciénagas.

A lo largo de los años, sus pobladores sufrieron el flagelo de distintos grupos armados ilegales y, por ende, muchas generaciones se criaron bajo la influencia del terror infringido por aquellos que creyeron que la violencia era el camino.

Abuelos, hijos y nietos, criados entre los departamentos de Bolívar y Sucre, donde la tierra es fértil para la agricultura y la ganadería, quedaron en el centro de las disputas territoriales de los grupos armados.

Fue allí donde la Fuerza Pública entró a jugar un papel fundamental. Hombres de tierra, mar y aire con gran valor, quienes, cumpliendo su deber constitucional, defendieron a la población y, actuando en el marco de la ética y el respeto por los Derechos Humanos, lograron asestar golpes certeros a los grupos armados, en operaciones tan exitosas que permitieron retomar el control en la zona y consolidar la seguridad en el territorio.

Esa victoria se la debemos al sacrificio, valentía y esfuerzo de todos nuestros hombres. Sobre sus hombros se han venido construyendo la paz y la prosperidad, una propuesta de esperanza, vida y desarrollo, que contrasta con la de siempre: violencia y muerte del enemigo.

Particularmente, los hombres de la Armada Nacional combinaron los esfuerzos para combatir a los grupos ilegales, con acciones 
tendientes a mejorar la calidad de vida de la población y fortalecer su relación con la comunidad a través de programas de acción integral.

La consolidación de la seguridad y el esfuerzo integral por satisfacer las necesidades de la población vulnerable de los Montes de María permitieron la transformación de los indicadores del bienestar social y económico de la región.

Somos conscientes de que todavía falta mucho y que las acciones que se tomaron fueron solo el inicio para intentar mitigar el sufrimiento y dolor de los pobladores de los Montes de María. Sabemos que cada víctima y sus familias le atribuyen un significado individual a su propia experiencia, a su propio dolor. Y que cada uno tiene derecho a contar su historia, y así sanar poco a poco sus heridas.

Estos testimonios son ejemplo de la fortaleza y la grandeza de la comunidad de la zona, y demuestran que con tenacidad y empuje se superan las peores pruebas de la vida. Siempre la virtud vence al mal, aunque a veces se demore.

Esa es la memoria que se reconstruye en este documento, fruto de un trabajo mancomunado entre grupos interdisciplinarios de la Armada Nacional y la Universidad Santo Tomás, que hicieron la labor de estudiar e investigar el contexto social, político, económico y militar de lo acontecido en los Montes de María.

El producto de dicho análisis es el libro que tiene usted en sus manos. Una reflexión juiciosa de una parte de la historia que vivió una región del país como consecuencia del conflicto y que se convierte en una oportunidad para garantizar la no repetición de estos actos de crueldad.

La vida me dio otra oportunidad no es solo el recuento de historias de dolor, es también la mirada sincera y optimista de quienes anhelan cambiar su propia historia, enmendar sus errores e imprimirle esperanza a sus vidas.

Además, es un aporte institucional al Sistema Integral de Verdad, Justicia, Reparación y No Repetición como parte del compromiso que tenemos con las nuevas generaciones de continuar en la construcción de la memoria y el tejido social para contribuir a restaurar la paz y alcanzar la reconciliación.

Almirante Ernesto Durán González Comandante Armada Nacional 


\section{Presentación}

La unión de voluntades de la Universidad Santo Tomás, a través su División de Ciencias Sociales, y las Fuerzas Militares de Colombia, por medio de la Armada Nacional, permitió el desarrollo de esta investigación, que hoy se presenta al público académico, científico y a la comunidad en general como un documento elaborado con rigor, que le permite al lector comprender mejor las dinámicas sociales, políticas, históricas y culturales de una región colombiana fuertemente afectada por la violencia: los Montes de María.

Para los colombianos, durante décadas fue familiar oír o ver en los medios de comunicación noticias que registraban la violación constante de los derechos humanos en estos territorios, ubicados entre los departamentos de Bolívar y Sucre.

Precisamente, los investigadores Daniel Garzón Moreno y John Valencia Riaño, nos ayudan a comprender los orígenes de la violencia en dicha zona en el primer capítulo de este libro, que se intitula "Dinámicas de la violencia en Montes de María". Se trata de un estudio historiográfico que además analiza el contexto político en el cual se desarrolla la violencia, teniendo en cuenta aspectos centrales como el control político de los grupos armados y sus posiciones extremas.

Nos adentra mucho más en la temática el segundo capítulo, denominado "Dinámicas de la violencia en Montes de María (19702015)", cuya autora es Ginneth Esmeralda Narváez. En esta parte del 
libro, se describen los grupos armados ilegales que han tenido injerencia en la zona, a través de características como modelos de guerra, tácticas, estrategias, recursos, alianzas y dominación territorial. Además, refiere algunas operaciones clave que ejecutó la Armada Nacional con el fin de permitir que el Estado retomara el control de la zona.

El contexto jurídico de cinco masacres ocurridas en los Montes de María, más exactamente en lugares como Pichilín (1996), Capaca (1999), El Salado (2000), Mampuján (2000) y Chengue (2001), se aborda en el tercer capítulo de este libro. Aquí se hace la reconstrucción de dichos casos en los que estuvieron involucrados grupos paramilitares. Además, se da cuenta del actuar de la Armada Nacional posterior a los mencionados hechos, desde la perspectiva del desarrollo jurídico.

El cuarto capítulo, de autoría de María del Mar Martínez y Camilo Andrés Castiblanco, se intitula "Las víctimas de la región de los Montes de María", analiza las afectaciones que la violencia tuvo en la población civil y los integrantes de la fuerza pública.

El libro termina con una serie de crónicas, escritas por Carol Malaver Sánchez, que hacen que esta investigación tenga rostro y se encarne en seres humanos, colombianos de a pie que merecieron siempre la protección del Estado, esa que por fin les llegó con la Armada Nacional, luego de haber sufrido por muchos años el dolor de la fría y descarnada guerra.

Esperamos que el documento contribuya a la consolidación de la paz en esta región biodiversa del territorio Colombiano, cuyo potencial económico y humano con seguridad logrará su desarrollo en el marco de un contexto de convivencia, paz y reconciliación.

Fr. Juan Ubaldo López Salamanca, O. P. Rector General 


\title{
Capítulo 1 \\ Configuración histórica y causas de la violencia en la región de Montes de María
}

\author{
Daniel Garzón Moreno* \\ John Valencia Riaño**
}

* Antropólogo con Maestría en Historia de la Universidad de los Andes.

** Economista, postulado a Magíster en Planeación para el Desarrollo de la Universidad Santo Tomás. 



\section{Introducción}

Entender las dinámicas de la violencia y el conflicto armado en la subregión de los Montes de María parte de que el investigador tenga una postura amplia sobre los múltiples y diversos aspectos en torno a la configuración económica, política y sociocultural que han envuelto estos territorios a lo largo de la historia contemporánea de Colombia. El despojo de tierras y la actual problemática de restitución en los Montes de María es un tema trasversal en este capítulo porque para poder dar cuenta de los diversos conflictos e intereses de los actores armados ilegales que han tenido presencia allí, se debe profundizar, desde una mirada historiográfica, en las dinámicas y el desarrollo económico de los municipios que hacen parte de los Montes de María. Asimismo, se debe abordar el contexto político en el que se desarrollaron los principales hitos de la violencia en esa parte del país, haciendo alusión al control político existente en la subregión y a la polarización social frente a los diferentes actores armados involucrados.

El tejido social que se fue construyendo a pesar de las grandes rupturas socioculturales en la subregión de los Montes de María por causa del conflicto armado es otro factor fundamental que se debe abordar de manera profunda, en tanto se pueden esclarecer las dinámicas que han generado a lo largo del tiempo las diferentes entidades institucionales y los movimientos políticos, para recuperar y recomponer un entramado de aspectos que conducen a la reparación 
simbólica y al crecimiento productivo de una de las zonas que más ha sido afectada por el conflicto armado interno colombiano.

Dentro de la historiografía que se ha desarrollado desde diferentes instituciones sobre el conflicto armado en los Montes de María, es usual que se haga referencia a la posición estratégica en la que se encuentran los 15 municipios que hacen parte de la subregión de los Montes de María ${ }^{1}$ (Blanco, 2011; Grupo de Memoria Histórica, 2011; Daniels y Múnera, 2011; Aguilera, 2013, 2014; Melamed, 2015), teniendo en cuenta que geográficamente es una región adecuada para la producción agrícola y ganadera, aspectos económicos cuya importancia ha sido reconocida desde la época colonial, aunque se ha venido transformando a lo largo del tiempo.

La abundancia de tierras fértiles para la agricultura y la ganadería, "su estratégica y crucial posición a medio camino entre el Valle del Sinú, las sabanas de Tolú o de Corozal y el puerto de Cartagena” (Blanco, 2011: 192), han hecho de esta región un punto de concentración para el desarrollo económico del Caribe colombiano debido a su importancia geoestratégica, porque el río Magdalena une a la costa atlántica con el interior del país "convirtiéndose en una zona de fuertes disputas por el posicionamiento y control territorial por parte de distintos grupos armados ilegales, lo que se evidencia en la alta intensidad del conflicto armado que ha dejado a su paso más de 50 masacres ocurridas en la región, como lo ha demostrado el Centro de Memoria Histórica”2.

Frente a esto, también señalar que el auge de la información y documentación disponible sobre el conflicto armado en los Montes de María es una consecuencia de la entrada en vigencia de la Ley 1448 de 2011, cuyo objeto es:

establecer un conjunto de medidas judiciales, administrativas, sociales y económicas, individuales y colectivas, en

1 La subregión de los Montes de María está conformada por los municipios de María la Baja, San Juan de Nepomuceno, El Guamo, San Jacinto, El Carmen de Bolívar, Zambrano, Córdoba (pertenecientes al departamento de Bolívar), San Onofre, Los Palmitos, Morroa, Chalán, Colosó, Ovejas, San Antonio de Palmito y Tolú Viejo (pertenecientes al departamento de Sucre). (PNUD Colombia, 2010, pág. 5).

2 http://www.marchapatriotica.org/index.php/noticias-marcha-patriotica-2/231-opinion-yanalisis/3351-la-concentracion-de-la-tierra-en-los-montes-de-maria-frente-a-los-acuerdos-dela-habana. Recuperado el 8 de diciembre de 2017. 
beneficio de las víctimas, dentro de un marco de justicia transicional, que posibiliten hacer efectivo el goce de sus derechos a la verdad, la justicia y la reparación con garantía de no repetición, de modo que se reconozca su condición de víctimas y se dignifique a través de la materialización de sus derechos constitucionales. (Ley 1148 de 2011)

Por tal razón, esta subregión en específico tiene gran importancia para la producción académica desde las ciencias sociales y políticas, también para los informes del Centro Nacional de Memoria Histórica (CNMH) como "La Masacre de El Salado: Esa guerra no era nuestra" en 2009; "La tierra en disputa. Memorias del despojo y resistencias campesinas en la Costa Caribe (1960-2010)" en 2010; y “Mujeres y guerra: Víctimas y resistentes en el Caribe colombiano" en 2011.

Desde finales de los ochenta y durante la década de los noventa, una serie de transformaciones hicieron de los Montes de María un lugar estratégico para los actores armados y el narcotráfico. La apertura económica y el desarrollo de la malla vial -Troncal de Oriente, que conecta el oriente y centro del país, y Troncal de Occidente, que conecta el norte y sur del país- fueron capitalizados por grupos armados y narcotraficantes. Estos últimos utilizaron las vías para transportar la cocaína producida en el sur de Bolívar y Bajo Cauca al golfo de Morrosquillo, lugar donde los ilícitos eran embarcados fuera del país. Por su parte, la guerrilla se valió de las ventajas geoestratégicas que ofrecía la zona para su lucha contra el Estado y las élites; los paramilitares arribaron no sólo para enfrentar a la guerrilla, sino también por alianzas con el narcotráfico. (Grupo de Memoria Histórica, 2011: 73)

La proximidad de los Montes de María al Golfo de Morrosquillo centró su atención en el Gobierno Nacional por la necesidad de retomar el control del territorio, que tanto guerrillas como carteles de la droga llegaron a tener en esta zona del país, dados sus intereses geoestratégicos y geopolíticos, como corredor de movilidad en el negocio del narcotráfico. Dado el incremento en la actividad militar, de acuerdo al número de combates que debía asumir el Ejército Nacional, 
la Armada Nacional progresivamente fue asumiendo tareas propias de la infantería de Marina, de ahí que en la década del setenta se vio la necesidad de iniciar formación en tareas de control territorial y de enfrentamiento terrestre a las guerrillas que empezaban a actuar en esta zona.

Los mares, ríos y costas eran el centro que inicialmente determinaba la labor de la Armada Nacional, sin embargo, pasaron a ser poblaciones enteras en donde esta Institución tuvo que hacer presencia por la falta de presencia estatal. En Montes de María, la Armada Nacional hizo presencia desde el año 1974 en la subregión, combatiendo y enfrentando los diferentes ataques de los narcotraficantes, en donde la muerte de Gonzalo Rodríguez Gacha aparece como una acción determinante en su interés de luchar contra el narcotráfico. La Armada Nacional tuvo que enfrentarse a carteles de la droga, a la vez que combatía ataques por parte de los otros grupos armados ilegales que hacían presencia en esta zona. Un caso se referencia en la muerte por degollamiento de oficiales, dado que los guerrilleros atacaban en la búsqueda de armamento.

La Armada Nacional enfrentó en la región de Montes de María la combinación de todas las formas de lucha, por intermedio de la Primera Brigada de Infantería de Marina y sus unidades adscritas en esa tarea, se vio comprometida a patrullar, controlar, vigilar, contener las amenazas bélicas y delincuenciales en esta zona del país. Dichas unidades en su proceso de fundación y consolidación fueron un referente simbólico de presencia, además del control estatal en esta región.

Durante el periodo de intensificación del conflicto armado en la zona, la Armada Nacional, a través de la Infantería de Marina, tuvo que neutralizar ataques de la guerrilla, enfrentar los campos minados, estar al frente de los combates en la zona, actuar en doble condición como soporte de la defensa marítima, así como apoyo estratégico y determinante a la seguridad nacional. También participaron en labores de defensa de la pesca tradicional y mantuvieron coordinación con las otras Fuerzas Militares en la búsqueda de acciones cívico militares, apoyaron la dinamización de la economía local, además de realizar apoyos a las obras de infraestructura vial, como por ejemplo está la troncal de Montes de María, también colaboraron en la construcción de escuelas en la zona, como se dio en Macayepo.

Como lo señaló el Señor Almirante Andrés Vásquez, a la llegada de la Armada Nacional a los Montes de María, luego de haber tenido 
nefastos resultados operacionales donde fueron las emboscadas y siembra de campos minados por parte de los frentes $35 \mathrm{y} 37$ de las FARC, se estableció que a pesar de que el aparato militar se había fortalecido con la implementación del Plan Colombia, más la política de Seguridad Democrática del Gobierno de Álvaro Uribe Vélez, seguía faltando el relacionamiento de la fuerza armada con la sociedad como un componente fundamental para la consolidación de la Armada Nacional en esa subregión. Para este objetivo, se instauró el Plan de Acción Integral dividido en tres importantes aspectos con la sociedad. El primero, la acción integral general, el segundo, la acción integral coordinada, y, por último, la acción integral resolutiva. Dentro del marco de la acción integral general, el Señor Almirante Vásquez explicaba lo siguiente:

Nos dimos cuenta de unas necesidades que tenía la comunidad, necesidades en asistencia médica, brigadas de salud o jornadas de salud, nos metimos en todas esas veredas para hacer jornadas de salud, a llevar allá el medicamento, el analgésico, el antibiótico, con nuestros médicos y con nuestros enfermeros. ¿Por qué se llama acción integral general?, porque es una acción integral o una actividad que realiza solamente la fuerza, en este caso, la Armada Nacional. (Almirante Andrés Vásquez, 2018)

Con la creación de la Casa del Almirante, se adelantaron acciones de acercamiento con la población civil en la búsqueda de mejorar las relaciones con los habitantes de la zona. La primera Casa del Almirante nace en San Jacinto Bolívar, bajo el mando de la Fuerza Naval del Caribe y liderado por el Batallón de Infantería de Marina No. 13, con sede en Malagana, Bolívar; con el gran objetivo de ser un espacio familiar en donde la comunidad no tuviera temor para compartir sus experiencias en el territorio e inquietudes sobre diferentes procesos con el apoyo fundamental de la Armada Nacional.

Seguidamente, el Señor Almirante Vásquez aclaró que para tener más impacto positivo en la sociedad se debía crear la acción integral coordinada con aliados estratégicos como lo fueron Acción Social, con los cuales se realizaron brigadas por la alta montaña para identificar las principales necesidades de las comunidades que viven en esa zona para poderlas satisfacer en conjunto con la Armada Nacional y los aliados mencionados. En cuanto a la acción integral 
resolutiva, con el propósito de resolver las principales problemáticas que ha tenido la población en la subregión de los Montes de María, se dio en parte con la alianza que se generó con la cadena de supermercados Carrefour para crear un negocio que permitiera fortalecer el desarrollo económico de la región donde, como se va a ver en el desarrollo del presente capítulo, los Montes de María se convirtieron en la despensa de productos agrícolas, tales como el aguacate, que en el caso específico de Carrefour se pasó de vender el kilo de este producto de $\$ 800$ pesos a $\$ 3600$.

En clave del Plan de Acción Integral con la misión de lograr la constitución de la región Montes de María como plan piloto de consolidación del territorio, se partió de la altísima complejidad humanitaria, como consecuencia de la intensidad del conflicto armado durante más de treinta años. En el mandato de Álvaro Uribe Vélez, 2002-2010, se definió el Plan Consolidación, en respuesta a los direccionamientos que se formularon en la Política de Seguridad Democrática, la cual planteaba el desarrollo de acciones articuladas entre las Fuerzas Militares, con el fin de retomar el control de la zona y lograr la neutralización de la amenaza enemiga. Los grupos armados ilegales salieron progresivamente de la zona, debido al evidente debilitamiento militar de la guerrilla gracias a las labores de inteligencia y los golpes a sus estructuras; y las autodefensas ilegales como parte de un proceso de desmovilización masivo de sus frentes, resultado de la negociación con el Gobierno Nacional.

Bajo esta premisa, este capítulo se divide en cuatro grandes secciones en las que se van a trabajar de manera transversal los aspectos económicos, políticos y socioculturales que han estado de la mano con el desarrollo y la transformación del conflicto armado en la subregión de los Montes de María. En la primera sección, se hace una descripción de la configuración histórica y económica de los Montes de María desde mediados del siglo XIX hasta la última década del siglo XX, para dar cuenta de los procesos y dinámicas económicas por los cuales ha pasado la región a trabajar bajo una coyuntura política que marcó el desarrollo social de la población y el inicio del conflicto armado en los municipios que conforman los Montes de María.

En la segunda parte del documento, se describen las actividades económicas de finales del siglo Xx que fueron transformadas por el nuevo modelo económico y la consolidación de los grupos armados ilegales en la región. En este apartado se desarrolla de manera crítica y 
analítica cómo dichas transformaciones empezaron a tener un fuerte impacto en la economía regional, y, por ende, en el crecimiento y posicionamiento de las diferentes guerrillas y luego de las Autodefensas Unidas Ilegales o mal llamados paramilitares, que usaron los Montes de María como un escenario de conflicto por el control territorial de las rutas del narcotráfico de esta región estratégica para esos fines ilegales.

En la tercera parte de este capítulo, se profundizará el tema de los impactos y las dinámicas socioculturales en los Montes de María que ha traído consigo el conflicto armado en la región. Este apartado busca dar cuenta no solo de las afectaciones que ha recibido la población civil por los diferentes actores armados ilegales, sino que también busca explicar desde un componente antropológico las consecuencias que esto ha traído para la región y su desarrollo, una cultura política de la región Caribe, el desplazamiento forzado, el desarraigo cultural y la actual problemática de la restitución de tierras.

Por último, en la cuarta sección, se analizará cómo por medio de las diversas intervenciones que ha hecho la Armada Nacional en los Montes de María, se ha fortalecido el sector económico y social de la región, estableciendo posturas críticas frente las nuevas dinámicas de desarrollo y los nuevos retos que ha tenido que asumir la región luego de una serie de masacres y desmovilizaciones por parte de las autodefensas ilegales, además del actual escenario del posconflicto.

\section{Configuración histórica y económica de la subregión de los Montes de María 1850-1998}

La historia de la subregión de los Montes de María está marcada por las constantes luchas por la tierra, por los procesos de transformación social y política desde sus inicios, cuando se encontraban allí los indígenas chimilas y zenués, quienes resistieron y lucharon por sus territorios para mantener su cultura a salvo de los colonizadores que los invadieron, hasta los años del conflicto armado interno colombiano, que ha dejado enormes huellas y consecuencias tanto en la población como en la economía local y regional.

Durante el año 1812 en Corozal (hoy municipio del departamento de Sucre), en la llamada Revolución de los Curas, o Revolución de las Sabanas, los sacerdotes Eustaquio Mateo Romero y su sucesor 
Lorenzo Pinedo, quienes a diferencia de los religiosos de otras poblaciones apoyaban el movimiento independentista, rompieron con la unanimidad de las Sabanas en respaldar la causa realista. Este hecho histórico cobra importancia en este contexto porque Corozal era el paso de comunicación obligado entre la sabana y los Montes de María y el Sinú, además se constituyó en un núcleo de importante circulación económica por contar con un estanco de aguardiente y con una destacada producción ganadera (Correa, s.f.). El Carmen de Bolívar fue el bastión en donde se ganó y se sostuvo el nuevo Estado de Cartagena, entre los premios que recibió esa localidad por tales méritos estuvo su nombramiento como capital del departamento de la Montaña de María, así como otorgamiento del escudo, la bandera del estado soberano de Cartagena. Cabe recordar que hoy comparten esa misma bandera Barranquilla, Malambo y Cartagena.

Este hito relacionado con la historia social de los Montes de María no solo da cuenta de la importancia geográfica que ha hecho parte de la gran mayoría de los estudios sobre la región, sino que resalta un punto de partida para entender las dinámicas internas de lucha y resistencia por las cuales han tenido que pasar a lo largo de los años los pobladores de los municipios que conforman la subregión. Inclusive hoy en día, más de doscientos años después de la llamada Revolución de las Sabanas, se vive en las veredas y corregimientos montemarianos una ilusión de liberarse de los yugos que han soportado por la constante presencia de grupos armados organizados ilegales, que tanto mal le han hecho a la región y al país.

Los Montes de María es una subregión de la costa Caribe con un gran potencial productivo por su ubicación, sus grandes propiedades naturales que permiten el cultivo de diversos productos agrícolas (Finagro, 2014), el cuidado ganadero, la utilización de los recursos forestales, riquezas de flora y fauna, y en los últimos años su aprovechamiento como sector estratégico para los megaproyectos de recursos extractivos. Los Montes de María abarca un territorio estratégico para los diferentes actores que han pasado por él, como los grandes terratenientes, los grupos al margen de la ley y los colonos extranjeros que ven en esta región una oportunidad para realizar inversiones generando acumulación y riqueza para sus arcas, aunque finalmente esto no afecta la calidad de vida de sus pobladores y el desarrollo de la región. Según el DANE, en el año 2005 el 92\% de la población rural de los Montes de María tenía condiciones de pobreza, encontrándose las 
mayores deficiencias en distintos indicadores como empleo, educación y acceso a los servicios públicos.

En los Montes de María, con una extensión de 6466 km², habi$\tan 438119$ personas, conforme al censo 2005. Sin embargo, se ha presentado una movilización masiva del campo a la ciudad por la presión de actores con intereses particulares, ejecutada mediante la acción de grupos armados ilegales. En 2005, el 55\% de la población de los Montes de María vive en la parte urbana y el $45 \%$ en el área rural (PNUD, 2010: 5).

Figura I-1: Aspectos sociales y agrícolas en la subregión de los Montes de María

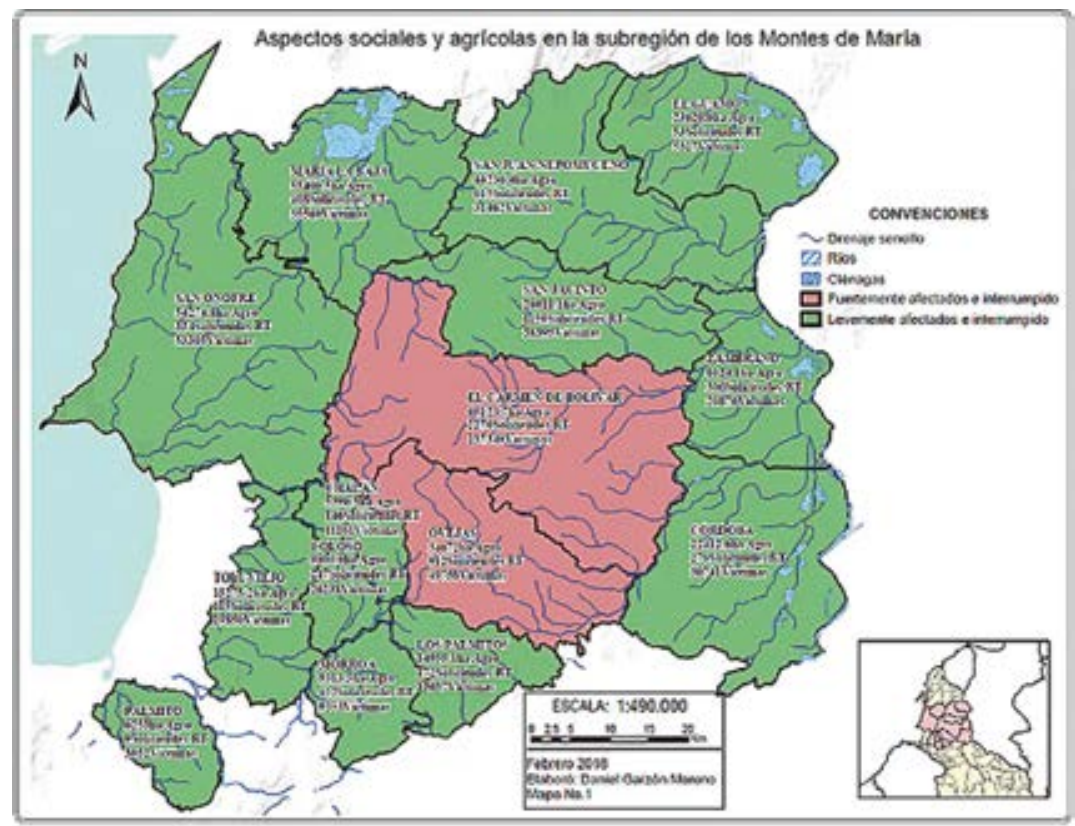

Los primeros pobladores de la región montemariana fueron los indígenas zenú pertenecientes a los grupos Panzenú y Finzenú, que compartieron territorios con los malibúes y los chimilas (Aguilera, 2013:4). Desde estas épocas de asentamiento indígena ya se tenía conocimiento de las grandes propiedades naturales del territorio para los distintos cultivos que iban llegando poco a poco. La población indígena 
aprovechó estas bondades geográficas para volverse experta en la agricultura, y su comercio se centraba en los alimentos cultivados, mediante una especie de sistema cooperativo.

El primer español en recorrer la región fue Pedro de Heredia, en 1534. Un año después, su hermano Alonso de Heredia fundaría la Villa de María La Alta, presumiblemente donde hoy se asienta el municipio de El Carmen de Bolívar. La fundación no tuvo éxito y ya para el año 1610 esta villa se había extinguido, sobreviviendo solo el nombre de "María”, como se conocería la serranía adyacente (Jimeno, 2005: 10). El territorio fue desaprovechado en un principio, porque los españoles no evidenciaban las propiedades y solo veían zonas boscosas y montañosas que no cumplían con las expectativas de los conquistadores; esta situación de abandono por parte de los españoles fue aprovechada por personas del común y asentamientos indígenas, que vieron en este territorio un sitio para escapar del yugo español.

Durante los siglos XVII y XVIII, se formaron los palenques fugados de las acciones de conquista de los españoles. En este periodo aparecieron los primeros asentamientos, se comenzaron a construir aldeas y se dio comienzo a los cultivos para el sostenimiento de los habitantes. Estos movimientos fueron de conocimiento de las autoridades españolas, por lo cual el 6 de agosto de 1776, en cumplimiento de la orden del gobernador de la provincia de Cartagena, don Antonio de la Torre y Miranda, se fundó la población de Nuestra Señora del Carmen (Aguilera, 2013: 4). Al observar el territorio y los avances logrados por los palenqueros en los asentamientos existentes, don Antonio de la Torre decidió organizar las calles, las ubicaciones de las aldeas y las funciones de los habitantes para el desarrollo del territorio; en este momento de la historia la región comenzó a ser de interés de las demás poblaciones por su ubicación geográfica.

\section{Las primeras actividades económicas de los habitantes de la región en los siglos XIX-XX y la creación de las organizaciones campesinas}

En el siglo XIX, los pueblos de la subregión Montes de María crecieron y atrajeron familias que expandieron las haciendas ganaderas. El médico José María Pizarro se estableció en el municipio de Ovejas y trajo de Cuba las mejores variedades de tabaco negro, que luego fueron 
cultivadas en la zona para el consumo interno y para la exportación. Además, se constituyeron casas comerciales que acrecentaron los negocios de la compra y venta de tierras y la ganadería (Aguilera, 2013: 5). La llegada de familias de diferentes partes del mundo, que vieron una oportunidad de consolidar su vida, fue la base para construir las actividades principales de agricultura y ganadería por las cuales la región sería reconocida a través de su historia, dando lugar a la implementación de una cadena productiva en la cual el patrón paga la jornada laboral con los alimentos para los campesinos y se generan las primeras ganancias gracias a los intercambios comerciales con los otros municipios.

En el informe que realizó el CNMH sobre las organizaciones campesinas en una parte de la subregión de los Montes de María, se puede evidenciar que los campesinos que fueron desplazados por la guerra de los Mil días a finales del siglo XIX, generó en Colosó, y en general en los Montes de María, una situación de rearticulación social y de organización del campesinado para el trabajo colectivo de la producción agrícola, con productos típicos de la región tales como el tabaco, el ñame, el ajonjolí, la yuca y el maíz.

Las comunidades campesinas que se fueron configurando en la zona de sabanas y parte de los Montes de María establecieron relaciones que proyectaban lo colectivo como un elemento fundamental para solventar en conjunto sus necesidades, y para desarrollar diversas acciones que les permitieran sobrevivir en medio de unas fuertes condiciones de pobreza y una historia de violencia. (CNMH, 2017: 42)

Lo que hoy en día se conoce como la subregión de Montes de María, en la época colonial también conocida como la Región del Carmen, hizo parte de la provincia de Cartagena y estuvo fuertemente ligada a las dinámicas del mercado de la Colonia de los diversos productos, como el tabaco, que salían del interior del país hacia el continente europeo. De ahí que la producción y la comercialización del tabaco hayan sido tantas veces estudiadas en el marco de la historia económica en Colombia (Viloria de la Hoz, 1999; Ríos, 2015), para dar cuenta de uno de los primeros productos de desarrollo económico regional en el siglo XVIII y que luego influyó en la transformación del 
uso de la tierra para entrar dentro de los modelos de mercado mundial a mediados del siglo XIX con los llamados estancos.

Por causa de la crisis económica que generó la competencia europea de la producción y exportación del tabaco, centros tabacaleros de gran importancia como los que se encontraban en Ambalema, en el Alto Magdalena, sufrieron grandes pérdidas económicas y su posterior extinción, debido a su "capacidad para adaptarse a las épocas de precios bajos en un mercado internacional cada vez más competido" (Blanco, 2011: 194), por la gran demanda externa del producto, "las óptimas condiciones naturales del suelo, el fácil acceso de los cosecheros a la tierra y la posición estratégicamente ventajosa, en el más importante cruce de caminos y rutas tanto terrestres como fluviales y marítimas entre esta región y el resto del país"(Blanco, 2009:102). Este producto constituyó una consolidación fuerte en la región y en el país mucho antes que el café, siendo el producto central de las relaciones económicas en estos tiempos analizados.

Para el cierre del siglo, tras crisis insuperables ante la baja de precios y la aparición de nuevos competidores en el mercado europeo, tanto Ambalema como los demás centros productores del interior andino para la exportación desaparecen como tales; solo queda en pie desde las primeras décadas del siglo xx la región tabacalera exportadora del Carmen (Blanco, 2011: 194). Los Montes de María y en especial Carmen de Bolívar no sintieron estos choques externos por tres principales razones: en primer lugar, por su ubicación geográfica, que permitía reducir costos en el transporte del producto; en segundo lugar, por la calidad del producto, dadas las bondades en el cultivo por la técnica y los materiales utilizados; en tercer lugar, por la cantidad de cultivos disponibles para la exportación, con mercados consolidados que no permitieron que la región se viera afectada por la caída de los precios.

Desde la década del sesenta el cultivo de algodón en Los Palmitos fue desapareciendo y el tabaco rubio y negro se redujo casi hasta acabarse en la mayoría de sus veredas, aunque todavía se produce en algunas comunidades como Sabanas de Pedro. En el presente, el cultivo de yuca dulce y amarga es uno de los principales sustentos de la economía campesina, seguido de actividades como la pesca, la cría de especies menores, la siembra de ají picante y el maíz, comercializados 
en Ovejas, Sincelejo, El Carmen de Bolívar y Barranquilla.

(CNMH, 2017: 49)

La economía tabacalera de la región del Carmen estuvo al servicio de la acumulación de renta capitalista, atrayendo desde muy temprano la inversión de capital mayoritariamente extranjero, que operando a través de empresas conocidas como "casas compradoras" o más apropiadamente, hoy día, como tabacaleras, las cuales acopiaban el tabaco producido en la subregión y, tras procesarlo, lo destinaban especialmente a la exportación en rama de miles de toneladas a Europa. Es la inmigración comercial o empresarial la que da lugar a la presencia extranjera en la comarca de empresarios como los Hollman, los Held, los Hamburguer y otros alemanes; los Frieri, Gallo, Volpes, y otros italianos; o los Barnier franceses, o los siriolibaneses, y algunos holandeses (Blanco, 2011: 194).

En la siguiente figura se evidencia el auge exportador sobre todo de la región del Carmen aprovechando la recesión europea y la crisis productiva en otras regiones fuertes en este cultivo.

Figura 1-2: Exportaciones colombianas de tabaco a Bremen, lugar de origen y volumen total, 1856-1871 (en zurrones)

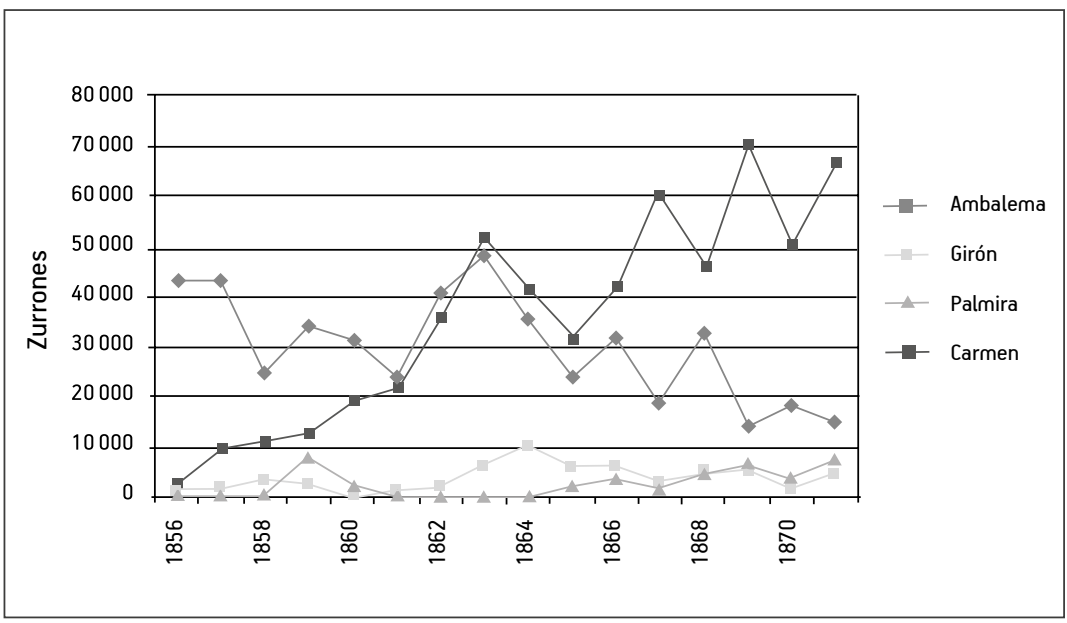

Fuente: Banco de la República de Colombia. 
En los Montes de María durante todo el siglo XIX y hasta entrado el siglo XX se mantuvieron grandes extensiones de tierras no ocupadas y baldías, que de hecho resultaron de fácil, libre y pacífica posesión (Blanco, 2011: 196). Por la herencia dejada por los conquistadores españoles, la región se caracterizó por la distribución equitativa de la tierra y por este motivo varios de los habitantes encontraron un lugar para ubicar su vivienda y su extensión de tierra para cultivo; repercutiendo en una cantidad menor de latifundistas a diferencia de toda la costa Caribe.

Figura I-3: Producción de Tabaco en el Municipio de Ovejas

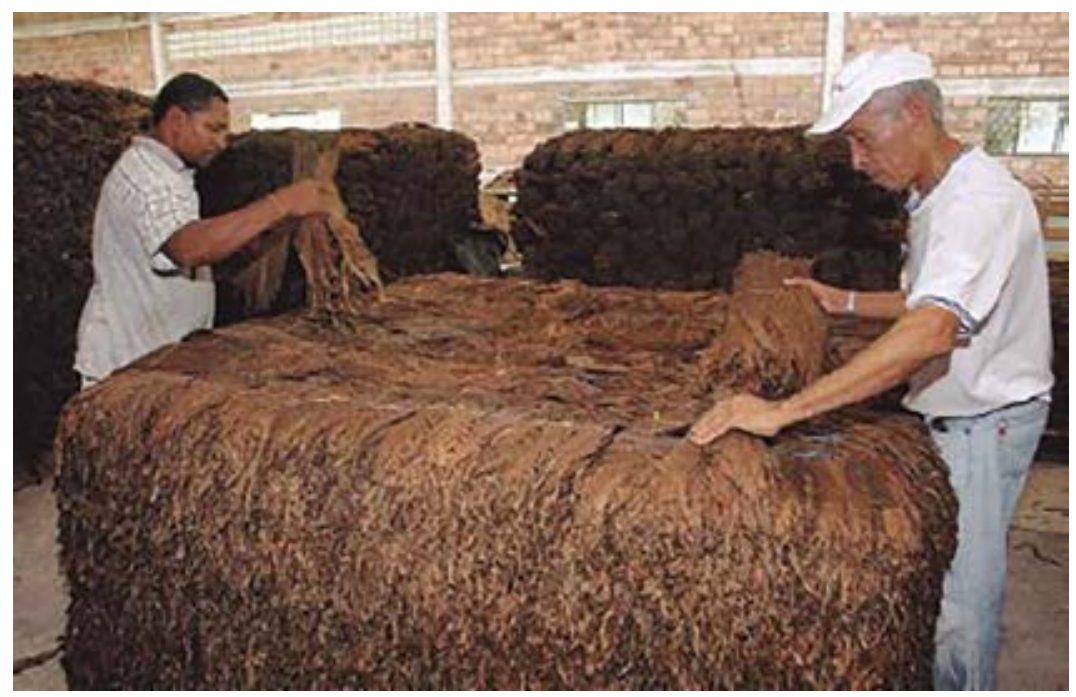

Fuente: El Universal (11 de noviembre de 2016). Disponible en http://www.eluniversal.com.co/sincelejo/ local/compania-esta-iliquida-para-comprar-produccion-de-tabaco

En la región no se tenía un proceso consolidado sobre otras actividades agrícolas, porque finalmente los pocos cultivos que existían, como plátano, maíz y cacao se producían para consumo interno y para intercambio con los municipios adyacentes; por lo tanto, no era un mercado fuerte ni reconocido para ser un potencial económico en la región. Como lo señaló el funcionario de la Asociación Nacional de Usuarios Campesinos de Colombia (ANUC), Richar May en la entrevista realizada por el equipo de investigación, la limitante en esta época era 
la gran concentración de los predios en latifundios con un cultivo de desarrollo precario, la cual no permitía una implementación en el desarrollo de la cosecha, un mejor tratamiento de la producción y un mejor aprovechamiento de la tierra, perdiendo las capacidades reales solo por cumplir los intereses de los grandes hacendados (R. May, comunicación personal, 5 de diciembre de 2017).

A pesar de esto, la región generaba intercambios comerciales con otros municipios y se convirtió en la despensa agrícola del Caribe entre las principales ciudades de la costa atlántica, y en epicentro de grandes progresos agrícolas así como de migración de personas que veían la oportunidad de trabajar la tierra para tener la oportunidad de encontrar un estilo de vida que les generara bienestar para sus familias; existía suficiente tierra para el que quisiera trabajar tanto como administrador de tierra de algún terrateniente, como para explotar terrenos baldíos.

\section{El comienzo de las organizaciones campesinas en los Montes de María}

El primer sindicato agrario de Colombia se constituyó en Colosó, en 1913, por el maestro de escuela Eduardo Arango y Córdoba. Estas organizaciones fueron el inicio de la conformación de los sindicatos campesinos creados en los decenios de 1930 y 1940 y formalizados con la Ley 83 de 1931 (Aguilera, 2013: 6). En las décadas de 1950 y 1960, los sindicatos de la Federación Agraria Nacional (Fanal) y la Asociación Nacional de Usuarios Campesinos (ANUC) nacieron con el fin de apoyar al Gobierno en la implementación de la reforma agraria, como puente de conexión para concientizar a los campesinos y terratenientes en la necesidad de la adecuada distribución de la tierra para aumentar la productividad, garantizando equidad y mejores condiciones sociales y económicas.

Las luchas campesinas en la región construyeron la unión de los campesinos, su lucha por mantener la productividad de la tierra, la construcción de su identidad como personas indispensables, productivas y con calidad de vida. Las organizaciones lograron el propósito de recuperar tierras en los años setenta con los primeros comités; pero su funcionamiento se vio afectado por la constante amenaza de los grupos guerrilleros, por la imposición de sus ideales y el asesinato 
de líderes gremiales por su compromiso en la creación de políticas agrarias como socio primordial del Gobierno.

Figura I-4: Movilización de la Asociación Nacional de Usuarios Campesinos (ANUC)

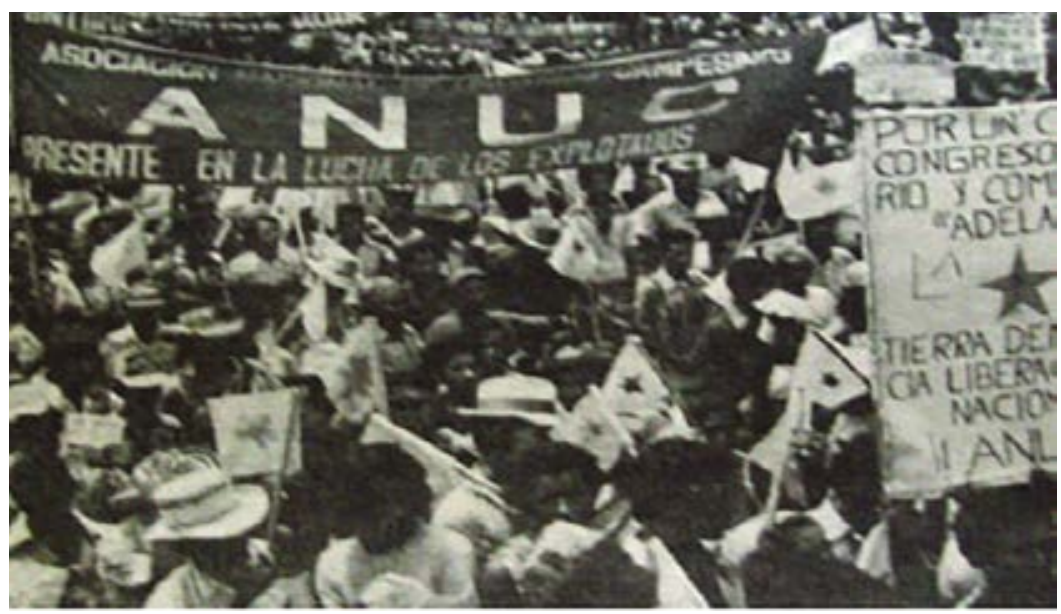

Fuente: Revista Semana (2003).

Los comienzos de las asociaciones en la región no fueron fáciles, más que en un aliado, se convirtieron en un problema para las relaciones entre patronos y los trabajadores de las tierras. En los años setenta, la ANUC se convirtió finalmente en el aliado del Gobierno para la reforma agraria y la adecuada distribución de la tierra, dando como resultado la titulación de la tierra a arrendatarios que por años habían labrado las fincas de sus patrones. Por esta razón, creció el temor por parte de los grandes terratenientes en perder sus parcelas por ser producidas por otros, por esta razón tomaron la decisión de despedir a sus trabajadores, creando un pánico colectivo y una desestabilización socioeconómica en la región.

Con la acción de la ANUC y el Incora con base en la reforma agraria (Ley 135 de 1961) impulsada por el Gobierno de turno, se logró gran parte de la distribución y titulación de las tierras proyectadas, lo que produjo tres resultados destacados: en primer lugar, el "premiar 
el trabajo realizado por los campesinos en su función de trabajar en las parcelas, volviendo productiva la región" (R. May, comunicación personal, 5 de diciembre de 2017).

En segundo lugar, "estos logros conseguidos con la reforma agraria le dieron sustento a las ideologías comunistas impulsadas por los grupos guerrilleros, respondiendo a la filosofía del trabajo comunitario de la tierra pasando por encima de la propiedad privada" (A. Hernández, comunicación personal, 2 de diciembre de 2017), y en tercer lugar, las acciones del Gobierno y las organizaciones generaron unas bases de violencia causadas por el conflicto impulsado por los grandes terratenientes mediante el despido de los campesinos trabajadores de sus tierras quienes quedaron sin empleo y por lo tanto sin ingresos básicos, que a su vez propició el ingreso de estas personas a los grupos ilegales; prometiendo beneficios económicos por su contribución a la lucha armada.

La debilidad institucional en la región causó la facilidad para que los grupos armados ilegales entrarán con acciones de control armado, causando cambios en los comportamientos sociales con la persecución a los dirigentes gremiales, y por otro lado ofreciendo "servicios de seguridad" para las actividades ganaderas de la región azotada por la delincuencia común (F. Blanco, comunicación personal, 11 de diciembre de 2017), ejerciendo de esta manera control sobre el comercio y la seguridad de las cosechas, para generar la confianza dentro de la población como mediadores de conflicto por la propiedad de tierras y el hurto de cosechas.

\section{Las actividades económicas de finales del siglo $\mathrm{xx}$ transformadas por el nuevo modelo económico y la consolidación de los grupos armados ilegales}

En la década de los noventa, con la apertura económica y la pérdida del comercio exterior del tabaco negro, del cual la subregión de los Montes de María era gran productor, se desencadenó una situación calamitosa desde el punto de vista social, político y económico, porque, como se explicó anteriormente, las únicas fuentes de empleo eran las compañías tabacaleras. Esto incidió negativamente e impactó en el pensamiento de los habitantes montemarianos; tal como lo señaló 
Moisés Morantes en sus relatos, los pobladores creían que el conflicto era una cosa de la serranía y del interior del país, y no parecía posible que los problemas fueran a llegar a esa región.

Las circunstancias de pobreza aunadas al desequilibrio de la estructura económica y social por el desempleo y por los hechos violentos en la región, fueron un caldo de cultivo para que las nuevas generaciones se vieran obligadas a encontrar nuevas formas de obtener recursos económicos, y así, la vocación campesina se fue perdiendo. Se atentó entonces contra la estabilidad social y cultural de la región, perdiendo así prácticas y saberes tradicionales sobre el uso y trabajo de la tierra.

Una de las principales consecuencias de los hechos de violencia [...] es la "desocupación del campo", generada por las masacres y la generalización del miedo en los municipios, especialmente durante el periodo de 1990 a 2005. En estos años la presión sobre las poblaciones fue tal que en la mayoría de los casos generó un abandono forzado de las tierras, lo cual suscitó a largo plazo un "recuerdo imborrable de un suceso atemorizante". Específicamente en la organización se "despierta temor", lo cual conlleva a reproducir una atmósfera de "inseguridad y desconfianza" e implica que "los miembros de las organizaciones se desplacen, dejando los procesos y los territorios". (CNMH, 2017: 96)

Ya en los años noventa en Colombia existió un claro compromiso de cambio de modelo económico que permitiera un crecimiento sostenido de los indicadores y mejorar el bienestar de los ciudadanos dispuestos a explotar los grandes recursos del país. Este proceso se vio marcado pero con un claro desajuste dentro de la cadena productiva que no permitía consolidar un sector productivo como el agrícola por ser el predilecto en las regiones como camino para surgir. Por otro lado, existía un contexto económico marcado por los cambios del modelo económico exigido por cuestiones del momento de la liberalización comercial impulsada en la región.

El proceso de apertura económica, puesto en marcha durante el Gobierno de César Gaviria, fue acompañado por la privatización de la Caja Agraria, que empezó a perfilarse 
como el Banco Agrario con una gestión de banco comercial y llamando a los clientes a ponerse a paz y salvo con su cartera. El resultado inmediato fue que el 90\% de los campesinos de Montes de María quedó fuera del sistema de crédito por morosidad. [...] La crisis del sector agropecuario afectó en mayor proporción a aquellos departamentos o subregiones con un énfasis agropecuario y altamente dependientes de los resultados de este sector. En Montes de María, región eminentemente rural y agropecuaria, los efectos de las políticas neoliberales se tradujeron en un empobrecimiento generalizado y una disminución contundente del grado de bienestar material de la región. Es justamente en la década de los noventa cuando se intensifica el conflicto armado en Montes de María. (PODEC, 2011: 24)

Fue entonces, a partir de 1990, cuando la economía regional caribeña y nacional entró en un proceso de orientación hacia los mercados externos. Como lo explican López y Castrillón:

Antes de esta liberalización, la política agrícola presentaba una condición dual, los productos que se exportaban se aislaban del comportamiento de los precios externos, y de otra parte se presentaba que los costos de producción eran superiores a los del mercado mundial que, a su vez, implicaban una desventaja para los productores locales frente a los importadores. (López y Castrillón, 2007)

Productos como el algodón, el arroz, el maíz y sorgo, la yuca, la palma africana, el banano, el tabaco, y todo el sector pesquero, se vieron fuertemente afectados por la apertura económica, ya que elementos como la eliminación del fomento de productores y comercializadores, que se dio en los momentos en los que ocurre una caída de los precios internacionales (Abello, 1997), el aumento de las importaciones, y las sobreproducciones subsidiadas por los países industrializados como Estados Unidos y China, entre otros, hicieron que la crisis de la región Caribe en el sector agrícola desembocara en el desempleo, en la disminución de la capacidad de compra y en el aumento de la economía informal y el narcotráfico, como principales afectaciones sociales (Marín et al., 2017: 135). 
La apertura económica tenía como propósito dejar atrás el proteccionismo en el cual estaba sumergido el país desde hacía mucho tiempo, y de esta manera permitir que la producción nacional fuera reconocida en otros países, incrementando las exportaciones y la inversión extranjera directa. El modelo no fue correctamente implementado, puesto que existieron grandes desventajas para los productos nacionales por los bajos costos de importación de materia prima y los estándares internacionales alcanzados por los competidores. Por lo tanto, la agricultura fue la más afectada por sus precarios procesos en algunos casos de producción y baja asistencia técnica con los campesinos, quienes vieron la pérdida de competitividad de sus productos, causando pobrezay desilusión en el campo, bases poderosas creadoras de violencia en una región netamente agropecuaria.

Mientras que a nivel nacional la preocupación que existía era la consolidación de un nuevo modelo económico y la renovación del Estado por medio de una nueva Constitución Política por construir, los grupos armados ilegales se consolidaron en la región, tanto las autodefensas ilegales como la guerrilla, pero en los finales de los ochenta y principios de los noventa varios de los grupos se sometieron al proceso de paz de los gobiernos de turno, situación que fue aprovechada por las FARC, que se consolidaron en los frentes 35 en el departamento de Sucre y 37 en el departamento de Bolívar.

En los años ochenta, aparecieron los primeros grupos de autodefensas ilegales en la región con el propósito de ganarse la confianza de los hacendados y la gente "pudiente"; muchos de estos grupos fueron armados por los propios ganaderos en un afán de tener certeza sobre la seguridad de la región para combatir a los grupos dedicados a la extorsión y delincuencia común. Se impuso una nueva forma de extraer recursos a través de "tributos", regular la economía, administrar justicia, brindar protección, prestación de servicios básicos y ejercer el monopolio de la coerción, y de esta manera nace el Bloque Héroes de los Montes de María (PNUD Colombia, 2010: 18). 
Figura 1-5: Evolución del conflicto armado (1990-2002); acciones guerrilleras más recurrentes (1990-2010)
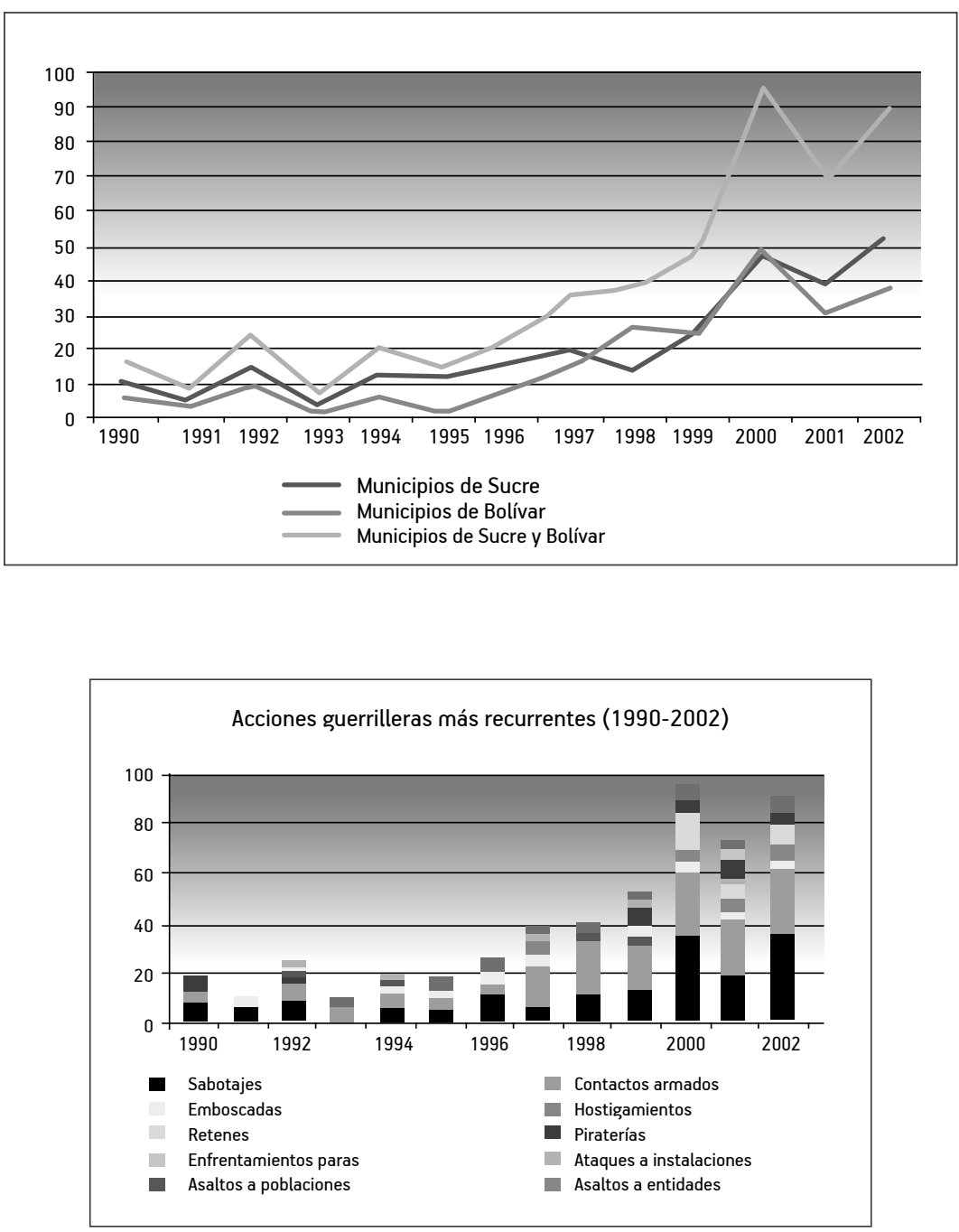

Fuente: Tomada del Observatorio del Programa Presidencial de Derechos Humanos y Derecho Internacional Humanitario (2003). 


\section{Las transformaciones económicas de los años noventa en la región influenciados por los grupos armados ilegales y sus intereses}

La relación del conflicto armado y la economía ha tenido una trascendencia a nivel global debido a la gran cantidad de guerras civiles que se han desarrollado a lo largo del último siglo. Los costos que tiene una guerra civil no se ven únicamente reflejados en la economía local, sino también en la dispersión de las poblaciones, y en la propagación de la miseria económica. Frente a esto, el economista Paul Collier señala que los factores que generan las guerras civiles "encierran a los países en un círculo vicioso en el cual el estancamiento económico genera guerra, lo cual produce un deterioro económico adicional y más guerra, y así sucesivamente en una trampa viciosa del conflicto" (Collier, 2004). Este círculo vicioso al que hace alusión Collier se puede ver reflejado en el caso de los Montes de María bajo tres dinámicas económicas que han caracterizado a la región, principalmente desde la última mitad del siglo xx y hasta la actualidad, como son los sectores agrícola, tabacalero y ganadero.

Estas tres actividades económicas han sido en gran medida generadoras, dinamizadoras o víctimas del conflicto armado de la región. De ahí que en este capítulo sea necesario profundizar en los principales aspectos sociales, culturales e históricos que ayuden a esclarecer las causas y consecuencias que han tenido los factores económicos en relación con el conflicto armado durante el periodo de tiempo trabajado en esta investigación (Marín et al., 2017: 120).

Los antecedentes solo muestran signos de grandes capacidades productivas en la región por su ubicación geográfica y sus propiedades en la tierra. En la región existían cultivos variados entre los que están los tradicionales maíz, yuca, ñame, algodón, arroz y los más importantes por su incidencia comercial eran el tabaco y el café; todo esto se consolidó con las acciones realizadas por los gobiernos de turno con la reforma agraria impulsada por el presidente Carlos Lleras Restrepo y las modificaciones por Misael Pastrana, al convocar a los ganaderos y principales hacendados con el pacto de Chicoral en 1972 para la creación de institutos que permitieron una adecuada 
producción y comercialización a través de los centros de acopio y apoyo del Gobierno3.

Desde principios del siglo $\mathrm{xx}$ se crearon organizaciones que reivindicaban el derecho a la tierra en San Onofre, Colosó y Ovejas. Estas acciones son precursoras de las llamadas Ligas campesinas, que posteriormente se formalizaron entre los años 1930-1940. Las acciones iniciadas por los sindicatos agrarios son retomadas en los años 60 por el Partido Comunista Marxista Leninista, que se constituye en la base social de la Asociación Nacional de Usuarios Campesinos - ANUc, organización fundada por el Gobierno de Carlos Lleras Restrepo en 1967. La ANuc tuvo un papel protagónico en Córdoba, Bolívar y Sucre (el departamento de Sucre fue creado el 18 de agosto de 1966), liderando la reivindicación del campesinado sin tierra y llevando a cabo 194 tomas o recuperaciones de la tierra entre 1971 y 1975. Entre los años 70 y hasta entrados los 80, los campesinos consiguieron que el Incora les titulara 546 fincas en parcelaciones colectivas y empresas comunitarias, que sumaban unas 120 mil hectáreas. (Podec, 2011: 37)

La economía sufrió cambios drásticos por la acción de las autodefensas ilegales y su relación con los ganaderos, con la idea de brindar protección de las tierras por el robo de cultivos que en un principio se cumplió, por lo cual fueron bien vistas sus acciones en algunas partes, porque existía delincuencia sobre los productores y terratenientes y la pérdida constante de cultivos y animales. Con ese propósito, los dueños de las tierras contrataron a estos grupos para brindar seguridad, y los mismos jefes de los grupos armados ilegales observando la extensión de la tierra proponían la cantidad de hombres necesarios y la "contribución a la causa" para el cuidado del territorio. Pero al pasar el tiempo, los nuevos propósitos de las FARC por el control territorial y el aumento de sus ganancias generaron un alza indiscriminada en la cuota para los dueños de las tierras, que finalmente no pudieron pagar, y en este punto empezaron las extorsiones, los secuestros y los "boleteos" de los terratenientes, teniendo control sobre las

3 Entrevista Miembro de la AnUc. 
extensiones de tierra estratégicas para la operación y producción de los cultivos a lo largo de la región (F. Blanco, comunicación personal, 11 de diciembre de 2017).

El objetivo central de los grupos armados ilegales era el control del territorio con fines lucrativos para el narcotráfico. Desde la década de los ochenta se sabe de la presencia del narcotráfico en la región. Por su ubicación y su calidad de corredor comercial como es el golfo de Morrosquillo, reconocidos narcotraficantes compraron tierras con el objetivo de buscar nuevas rutas de embarque de narcotráfico y lavado de dinero provenientes de estos negocios; estos personajes aumentaron las autodefensas ilegales para la protección y control del negocio. Por su posición geográfica, el golfo es una zona estratégica para el tráfico de cocaína, dada su cercanía con los países centroamericanos como Panamá, Haití y República Dominicana, convirtiéndose esta como centros de acopio para su posterior entrega a los carteles en Estados Unidos. Pero también por su cercanía con centros de producción, la coca llegaba al golfo y se embarcaba con rumbo al canal del Dique para ser enviada al puerto de Barranquilla (Usaid, 2016:38).

Por este motivo, muchas de las tierras fueron controladas tanto por las FARC como por las AUC, para cultivar, procesar y almacenar la droga, que se convirtió en un negocio rentable para estos grupos; pero causaron traumatismos en las relaciones sociales por los despojos de tierra (Reyes, 2010), campesinos sin trabajo y el temor de trabajar la tierra, las relaciones económicas, el encarecimiento de los productos y el aumento de la pobreza campesina.

Mientras tanto, las actividades económicas se deterioran por las plagas de la violencia y el miedo. La violencia empezó a causar traumatismos claros en las relaciones económicas de la región, alteraciones en los títulos de tierras, disminución significativa de los cultivos, temor de los empresarios que ocasionó cierres de las empresas, y quiebra de tenderos. Pero lo único claro es que la región con sus riquezas naturales permitió la constante oferta de productos en los mercados y no existió desabastecimiento de alimentos; en esto coinciden muchos de los pobladores de la región de la época (R. Lazcarro, comunicación personal, 9 de diciembre de 2017).

Las actividades económicas se vieron afectadas por un conflicto armado del cual no tenían la culpa, pues su única responsabilidad era vivir en un territorio de interés de las autodefensas ilegales, guerrilleras, de capos del narcotráfico. El tabaco, con apoyo de industrias 
americanas y alemanas, con grandes inversiones, hasta convertirla en uno de los principales exportadores, fue una de las principales actividades de la región y fue la base de la ocupación de sus habitantes. El tabaco, después de la industria de las flores, es el producto que más requiere mano de obra (Menco, 2012), y por lo tanto la mayor cantidad de población de la región tenía que ver con esta actividad económica. La producción de tabaco pasó de generación en generación y se trasladaba a las casas de los habitantes en donde existían minifundios y era la oportunidad de trabajo de todo el núcleo familiar; sin embargo, esta industria creó riqueza solo a unas personas (A. Redondo, comunicación personal, 12 de diciembre de 2017).

Pero en estos años existieron dos grandes desafíos, los cuales debilitaron el poder económico de influencia en la región con respecto al tabaco: En primer lugar, el conflicto con los secuestros, las amenazas por tener el control armado sobre la tierra que causó despojo de tierras, pérdidas de cultivo por falta de mano de obra y atentados a las fábricas directamente. En segundo lugar, la campaña nacional "No fumes" impulsada por el gobierno como política nacional de interés en apoyo a las políticas mundiales por las enfermedades causadas por el cigarrillo, disminuyó considerablemente la comercialización de tabaco negro, ya que por esta razón el mercado requería tabaco rubio, del cual era totalmente diferente la producción y se perdió el valor agregado de la producción del tabaco negro Montemariano. (A. Redondo, comunicación personal, 12 de diciembre de 2017)

Esta política trajo como consecuencia el cierre de tabacaleras de importancia en la región como Tabacos Bolívar, Tabagama y Tabacos del Caribe, la única que sobrevivió a este conflicto por su traslado a Cartagena y siguió dando apoyo para la producción sin dejar que se perdiera el tabaco en la región fue Espinoza y Hermanos Tabaco (A. Meza, comunicación personal, 5 de diciembre de 2017). En un segundo escenario se encontraba la agricultura, que se vio seriamente afectada por el despojo de tierras y la venta masiva de fincas al Incora a bajos precios, esto con el fin de alejarse de la violencia y ceder a los propósitos de los grupos armados ilegales en tener el control de los territorios. 
La agricultura es de los renglones más importantes de la economía en el Caribe Colombiano, de acuerdo con los datos de la Secretaría de Agricultura y Desarrollo Rural del Departamento de Bolívar, el $48,29 \%$ de los habitantes se dedican a labores de cultivo de alimentos y el cuidado de ganado. El 19,5\% del territorio de la región está destinado para el cultivo y la producción agrícola de diferentes productos tradicionales, siendo un porcentaje muy bajo para la capacidad de los suelos de la región; esta inadecuada distribución de la tierra no permite el crecimiento de la producción de alimentos, generar los empleos adecuados para la población y llevar a cabo los proyectos productivos necesarios.

A pesar de que entre el periodo 2001-2010 la siembra de hectáreas ha experimentado tasas de crecimiento hasta de $57 \%$, pasando de 53859 hectáreas en el año 2001 a 85082 en el año 2010 (Cámara de Comercio Cartagena, 2012). En este sentido, se evidencia el resultado de la desmovilización de los grupos armados ilegales, sin embargo aún es muy bajo el aprovechamiento de la tierra para las actividades agrícolas, ya que la gran acumulación de tierras por parte de diferentes actores se realiza para otros fines.

Figura I-6: Área sembrada y cosechada en Zodes, Montes de María, Bolívar 2000-2010

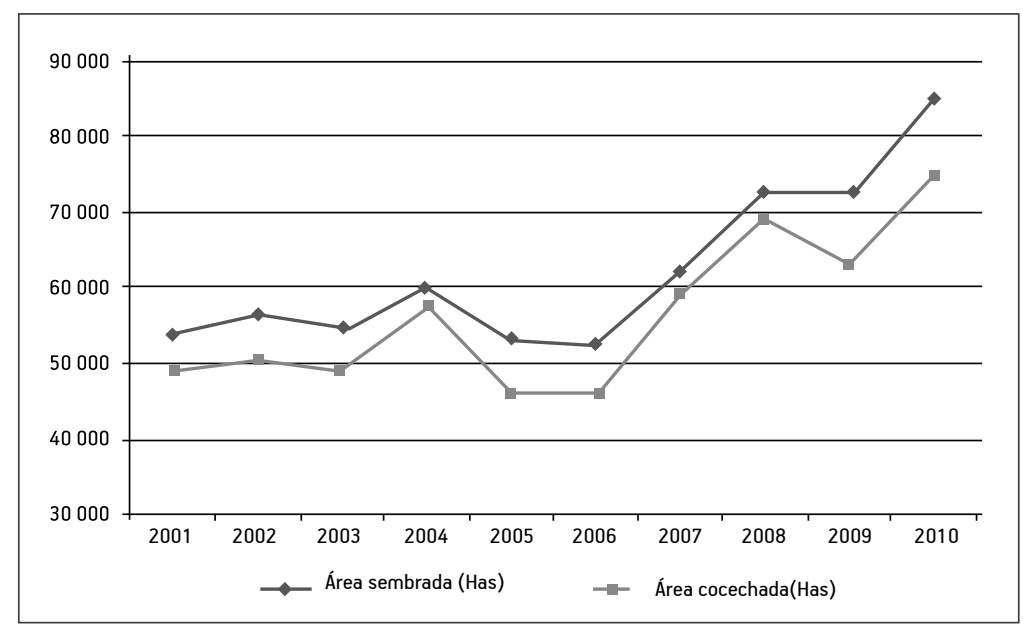

Fuente: Cámara de Comercio Cartagena (2012). 
En lo anteriormente descrito y según se demuestra en la figura I-6, se observa que la actividad agrícola en los años fuertes del conflicto, entre 2002-2006, era mínima y reducida por las acciones violentas y el abandono de las tierras. A partir de 2007, en donde existió el control territorial y armado por parte de las fuerzas militares, se generó confianza por parte de la población para volver al campo a trabajar con la ayuda de los programas del Gobierno y la intervención de diferentes instituciones con confianza en el potencial de la región.

El aguacate en un principio se conoció como el oro verde, esto como resultado de la excelente calidad de producto dado, el alto porcentaje producido y los buenos precios obtenidos con diferentes socios comerciales. El cambio fuerte se evidenció posterior a la terminación de la violencia, donde llegó acompañado de una plaga que acabo con varios cultivos en donde muchos campesinos y empresarios no pudieron recuperar el cultivo y por lo tanto la producción cayó de manera abrupta; como se mostró en la figura I-6, sigue siendo de importancia en la estructura agrícola de los departamentos por la intervención de los programas de entidades técnicas del Gobierno mejorando la técnica de producción y los programas de comercialización del producto, el cual es de interés de mercados como el Europeo.

Figura 1-7: Estructura agrícola, departamento de Bolívar

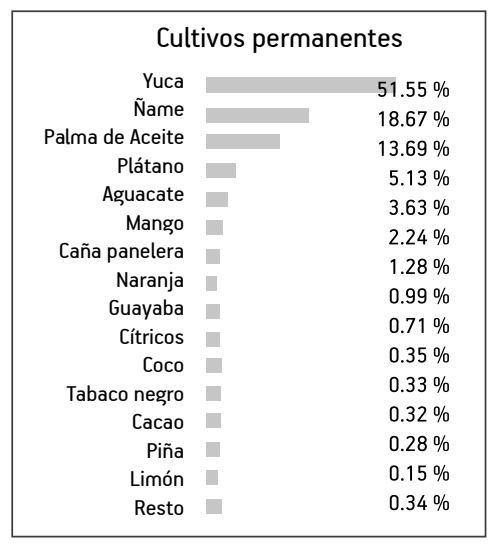

\begin{tabular}{|c|c|c|}
\hline \multicolumn{3}{|c|}{ Cultivos transitorios } \\
\hline Maíz & $\square$ & $54.37 \%$ \\
\hline Arroz & 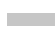 & $29.61 \%$ \\
\hline Melón & 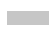 & $5.28 \%$ \\
\hline Ají & 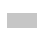 & $3.73 \%$ \\
\hline Ahuyama & 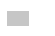 & $2.89 \%$ \\
\hline Frijol & $\square$ & $1.31 \%$ \\
\hline Tabaco rubio & I & $0.69 \%$ \\
\hline Ajonjolí & 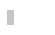 & $0.64 \%$ \\
\hline Sorgo & 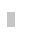 & $0.51 \%$ \\
\hline Patilla & 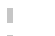 & $0.40 \%$ \\
\hline Algodón & $\|$ & $0.39 \%$ \\
\hline Berenjena & $\|$ & $0.10 \%$ \\
\hline Pepino & & $0.04 \%$ \\
\hline Hortalizas varias & & $0.02 \%$ \\
\hline Col & & $0.01 \%$ \\
\hline Resto & & $0.02 \%$ \\
\hline
\end{tabular}

Fuente: Ministerio de Comercio, Industria y Turismo (2017). 
Figura I-8: Estructura agrícola, departamento de Sucre
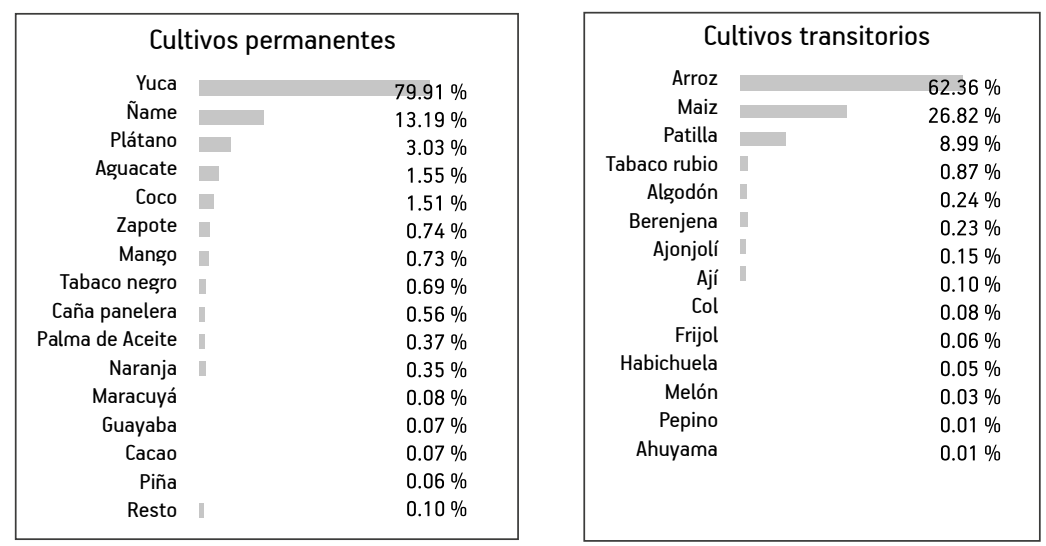

Fuente: Ministerio de Comercio, Industria y Turismo (2017)

Otro producto de importancia es la palma de aceite, que empezó a producirse a finales de los años noventa, a través de un modelo de alianzas productivas entre pequeños, medianos y grandes productores liderado por el grupo Oleoflores (El Espectador, 2017). En la región de María la Baja, se evidencia la mayor cantidad de producción de palma esto con apoyo del Gobierno, empresarios y asociaciones, se destacan las técnicas productivas y el adecuado proceso en la prevención de enfermedades sobre los cultivos. Esta actividad ha tenido crecimientos a lo largo del tiempo en la región por los apoyos dados por diferentes organizaciones y las rentabilidades por hectáreas para los cultivadores que según Oleoflores oscila entre dos a tres millones de pesos al año por hectárea.

A pesar de la disminución de los cultivos, nunca se dejó de cultivar, se encareció la canasta familiar por la disminución de oferta de productos por la baja cantidad de mano de obra y los cultivos fueron acabados por los grupos armados ilegales para cumplir con el objetivo de volver selva los campos para sus actividades delincuenciales como el secuestro y el tráfico de drogas. Pero los cultivos tradicionales se mantuvieron cultivándose con controles y limitantes por los grupos ilegales (A., Redondo, comunicación personal, 12 de diciembre de 2017).

Un actor de importancia y una de las principales razones para mantener la producción de alimentos fue la ANUC, con su ideal de 
potenciar las tierras adquiridas para mejorar las condiciones de vida, familiares y comunitarias, partiendo de la base de que la tierra es para quien la trabaja. Dicha organización logró unir esfuerzos entre los campesinos para mantener la producción en cada uno de los municipios (USAID, 2016: 21).

En un tercer escenario, está la ganadería, una de las grandes potencias económicas junto con el tabaco que fue directamente afectada por el conflicto, ya que los ganaderos, que impulsaron a estos grupos por cuestiones de seguridad y acumulación, se volvieron los enemigos principales, y comenzaron los secuestros y las extorsiones para obtener el control de las extensiones de tierra. La ganadería extensiva es una de las actividades más importantes de la subregión y del Caribe colombiano en general, si se tiene en cuenta la cantidad de hectáreas usadas para llevar a cabo la actividad. Según las secretarías de Agricultura y Desarrollo Rural de los departamentos de Bolívar y Sucre, las tierras de pastos ocupan el 75,3\% del total de área sembrada.

La producción ganadera de la región ha tomado relevancia a nivel nacional por las características de los animales y la calidad de pastos usados para la crianza que mejoran la calidad de los animales. La economía ganadera de la región es de características mixtas, está constituida por tres tipos de producción o explotación: cría con ordeño o doble propósito, carne y leche; la explotación doble propósito en los Montes de María tiene una participación del 87\% de la población bovina en Bolívar y del 93,5\% en Sucre (Promontes, 2003).

Todos estos hechos causaron en algunos casos la venta de tierras a los propios grupos ilegales; otros optaron por la venta a bajos precios al Incora y el éxodo a otras regiones para proteger la vida. Esto era llamado la "incorada", como lo señalaba el coronel Hernández en una entrevista realizada; y otros simplemente fueron asesinados o desaparecieron dejando la tierra abandonada. Así, se produjo el fin de la actividad en varios de los municipios de la región, entre los que se destaca San Onofre, que no ha podido recuperar su vocación ganadera y se quedó con la agricultura como medio de subsistencia (S. Revollo, comunicación personal, 11 de diciembre de 2017).

Por último, se encontraba el comercio general como una salida y una segunda opción para muchos de los campesinos desplazados; algunos tuvieron la oportunidad de montar sus negocios y volverse tenderos, comerciantes de frutas, verduras y productos básicos de la canasta familiar. Pero lastimosamente, este sector fue víctima 
de las acciones de los grupos, con dos hechos específicos: el primero, los saqueos a los negocios con la excusa de contribuir a la lucha subversiva para el abastecimiento de alimentos, y el segundo, la compra de productos pero condicionada a que si el comerciante le vendía de igual manera a otros grupos armados ilegales, destruirían la tienda. Por estos motivos, muchos tenderos tuvieron que cerrar sus negocios por las represalias y por miedo a las amenazas de los grupos armados ilegales (H. Pérez, comunicación personal, 12 de diciembre de 2017).

\section{Las nuevas actividades económicas en la región}

El gobierno y la empresa privada idearon varias estrategias para la recuperación del campo en su productividad y beneficios para los campesinos. Entre estas estrategias se encuentra renovar los cultivos y apostar por nuevos productos para generar mayor competitividad a la región, y uno de los resultados fue la elección del cultivo de la madera teca. Es un cultivo impulsado por el Conpes 2003 con apoyo del Gobierno y la empresa Argos, en retribución a sus emisiones de carbono por su actividad económica. Pusieron sus ojos en tierras de San Onofre y Carmen de Bolívar, por la ubicación geográfica y el comportamiento del clima necesario para el cultivo. Al ser un proyecto creado a través de la Fundación Crecer en Paz, no ha estado exento de las críticas de diferentes actores por ser un monocultivo, tener consecuencias sobre el medio ambiente y por la compra irregular de predios a altos costos para los terratenientes que previamente habían comprado a precios irrisorios a campesinos dueños de hace mucho tiempo; estas polémicas seguirán mientras no exista un control de las entidades correspondientes y se valore si el trabajo realizado realmente es beneficioso para la región.

Argos cree que en la región pueden convivir modelos de pequeña propiedad y agroindustria, pues este proyecto hace parte de la implementación de los acuerdos de paz, en los que la zona de reserva campesina y la economía familiar de los pequeños productores juegan un papel preponderante (Fundación Semana, 2015). Las actividades agrícolas, por otro lado, han sido impulsadas por organizaciones gubernamentales y no gubernamentales motivando a los campesinos para empoderarse como emprendedores y ver el campo 
como una empresa, una organización con los procesos y acciones adecuadas que genera bienestar y desarrollo para la región.

El café es uno de los cultivos que revive gracias al emprendimiento de un grupo de campesinos de la vereda el Bongal, cuya producción, sin pertenecer a ninguna asociación cafetera, es comprada por un microempresario que creó una franquicia llamada Cerro Maco Café, un grano inorgánico utilizado para hacer licor de café, tortas de café y granizados de café. Este negocio se maneja a través de franquicias y se ofrece en varios municipios con el propósito de divulgar las propiedades de este producto para que tenga mayor reconocimiento (M. Morante, comunicación personal, 5 de diciembre de 2017).

El SENA, en su objetivo de fortalecer su política de inclusión social y mejoramiento de la productividad, se convierte en el aliado estratégico en acompañamiento de proyectos productivos y ejecución de procesos de formación en asocio con la empresa privada, instituciones y las comunidades rurales para la creación y consolidación de proyectos productivos para favorecer en principal medida a los pequeños productores en actividades como la apicultura, cacao, ají picante, plátano, leche, palma de aceite, frutas, hortalizas y la piscicultura (SENA, 2016). Esta última actividad impulsada en municipios como San Onofre y Chalán, en donde de acuerdo con su compromiso les entregan una cantidad de peces que posteriormente son comprados por las mismas entidades para su comercialización (F.Zambrano, comunicación personal, 8 de diciembre de 2017); esto permite el regreso de muchos campesinos a las actividades agrarias por ver el apoyo institucional.

Un actor importante para impulsar los diferentes proyectos productivos y consolidar las alianzas entre los campesinos es la Armada Nacional, ya que por medio de sus canales de comunicación, como la emisora y la información dada en la Casa del Almirante, la población tiene conocimiento sobre las diferentes convocatorias de las entidades públicas para obtener recursos para llevar a cabo proyectos productivos e impulsar el campo siendo el gran desafío de la región para consolidar un modelo productivo de interés nacional.

Todos estos proyectos sobre el papel son buenos y han existido avances, pero a las autoridades y a los habitantes en general les preocupan las actividades realizadas por la juventud de la región, puesto que la mayoría de jóvenes no sienten un incentivo por cultivar y seguir las tradiciones del campo, y se dedican a actividades como el mototaxismo, 
una actividad informal que tiene presencia en toda la región y a nivel nacional, y que se convirtió en la primera oportunidad de los jóvenes en su mayoría de obtener ingresos para ellos y sus familias por falta de empleo y oportunidades de estudiar. En la región se evidencia una gran cantidad de motocicletas que son usadas con fines de transporte de productos y de personas, lo cual se ha convertido en un problema para las autoridades locales por la falta de seguridad y el surgimiento de otros negocios que se mueven alrededor de esta actividad.

\section{Impactos y dinámicas socioculturales en los Montes de María}

Los impactos socioculturales "incluyen tanto los efectos que surgen con la puesta en marcha de los proyectos y políticas, como la manera en que éstos se valoran, interpretan o resisten, se les dé sentido y se incorporan a la vida cotidiana" (Serje, 2010: 17). En el caso específico de la subregión de los Montes de María, donde hubo un desarraigo, desplazamiento y desalojo de la población campesina por parte de los grupos armados ilegales, generó que los agricultores de la región cambiaran sus herramientas de trabajo por armas tanto estatales como ilegales, generando así un vacío en los campos y una gran pérdida cultural debido a la falencia de la vocación agrícola.

El impacto sociocultural y el cambio en la sociedad fueron factores sustanciales y se fueron dando paulatinamente en la subregión de los Montes de María, lo que permitió que las nuevas generaciones buscaran actitudes y símbolos de poder a través de los grupos armados ilegales. Las personas que fueron víctimas del reclutamiento forzado que hacían presencia en ese territorio lo hicieron en su gran mayoría por causas económicas y no ideológicas ni de estatus social. La violencia que generó la fuerte presencia de las diversas guerrillas, pero sobre todo de las autodefensas ilegales en los Montes de María, tuvo un impacto en el tejido social de sus pobladores, ya que se generó un desarraigo sociocultural, lo cual es visto incluso como algo peor que el desplazamiento forzado para esta subregión debido al impacto negativo sobre el núcleo social. El alto porcentaje de asesinatos a hombres, como un ejemplo de lo anterior, afectó las relaciones de parentesco y parentales en la región, dejando como una de las múltiples consecuencias la carga de la educación y el sustento de los hijos y de las futuras generaciones. 
El accionar paramilitar no sólo fue un factor de alteración, generador de caos y desorden, sino también constructor de un orden y de una gramática social, ilustrada con lo acontecido en San Onofre y sus corregimientos. Esa construcción implicó un complejo, sostenido y constante proceso de control, regulación y disciplina de la vida social, donde se moldearon cuerpos, se resignificaron espacios, se nombró y se localizó la diferencia, y se construyeron formas específicas de relación social, de ser hombre y ser mujer. (Grupo de Memoria Histórica, 2011: 80)

Frente a lo que señala el informe del Centro Nacional de Memoria Histórica ( $\mathrm{CNMH}$ ), es importante resaltar que el accionar de las autodefensas ilegales y la guerrilla, como factor dinamizador social y simbólico dentro de la cultura de la región, hizo que se resignificaran lugares y actividades específicas para poder reconfigurar el tejido social y continuar con un proceso de duelo en el que se pudieran reparar simbólicamente el sufrimiento y las acciones violentas que sufrió gran parte de la población de los Montes de María. Un ejemplo claro frente a esto es el documento titulado "La Tarima", el cual refleja la resistencia civil de los Montes de María escrita por Moisés Morante frente al silencio que se impuso en la región por parte de los grupos armados ilegales, en el cual se explica que por medio de los festivales que se realizan a lo largo del año los pobladores podían subirse a la tarima y cantar las diferentes experiencias personales sobre el conflicto. Como lo señala el autor del libro, este fue de los pocos aspectos culturales que no fueron permeados por los grupos armados ilegales, es más, ellos también participaban en esos encuentros musicales.

Las dinámicas sociales en la subregión de los Montes de María fueron cambiando a lo largo del tiempo, ya que se fueron permeando por los diversos grupos armados ilegales en todos los lugares de relacionamiento público como las plazas, colegios, iglesias y demás. Como lo explica el habitante e historiador Moisés Morante, ya no se sabía si el vecino era de un bando o del otro, por lo que se prefería no abordar ningún tema comprometedor. Se plasmaron algunas estructuras semánticas como mecanismos de defensa para mitigar el efecto del conflicto que se vivía internamente. El compadrazgo se perdió porque ya no se sabía si los vecinos de la comunidad hacían parte de una 
corriente política u otra. Incluso hacer favores dentro de las comunidades se volvía algo pecaminoso, por creer que se estaba haciendo parte de algún grupo. Sellegó a los asesinatos selectivos por la calumnia que se generaba por estar con ciertas personas. "En el Carmen de Bolívar la gente no sabía por qué se moría" (M. Morante, comunicación personal, 5 de diciembre de 2017).

La no restitución consolida unos procesos complejos, que van desde la concentración en el uso del agua, los monocultivos de agroexportación que están inundando la región y que también influyen en que se pierda la tradición campesina y las formas de cultivar la tierra que tenían estos campesinos que no han retornado a su tierra [destaca Ferro].

Bajo este contexto, se habla de orfandad estatal cuando se habla de las masacres de El Salado y Macayepo, ya que dicho abandono permitió que los grupos armados ilegales pernoctaran en las poblaciones involucradas de manera constante, lo que generó una permisibilidad de la gente por responder a una estética que genera un estatus social como lo son las cadenas oro, los fusiles y los demás objetos que dan cuenta no solo de un alto poder adquisitivo, sino también del poder territorial que el Estado no estaba ejerciendo. El poder que se demuestra en un uniforme y en un arma es muy cotizado por las personas que no tienen mucho que perder y sí mucho que ganar, como lo explicaba Moisés en sus relatos.

El impacto que tuvo negativamente la constante presencia de los diversos grupos armados ilegales en la región hizo que por la naturalización de acciones cotidianas por parte de los combatientes de los grupos guerrilleros, o de las autodefensas ilegales en las veredas y corregimientos de los municipios que conforman los Montes de María, tales como pernoctar, lavar ropa o tener relaciones sentimentales, se estigmatizaran las poblaciones tanto de guerrilleros como fue el caso de El Salado, o autodefensas ilegales en Macayepo. Según un líder campesino de Ovejas, Sucre, los pueblos que más sufrieron el asedio de las FARC fueron Los Palmitos, Ovejas, El Carmen, San Juan Nepomuceno y San Jacinto. A su juicio, esta guerrilla "buscaba un posicionamiento político e ideológico, hubo zonas que fueron controladas totalmente por ellos, estaban en los caseríos las 
24 horas del día, e impusieron una disciplina militar entre la población” (Verdad Abierta, 2014) ${ }^{4}$.

Las FARC lograron tanta presencia en la zona que los campesinos aún recuerdan los campeonatos de fútbol que se jugaban en la región en los que se obligaba a sus organizadores a aceptar un equipo conformado por guerrilleros. "Su uniforme era camuflado y colgaban los fusiles en las porterías. Era como una forma de relacionarse con la comunidad, de mostrar su parte social, cultural”. (Verdad Abierta, 2014)

Este tipo de afirmaciones hacia la sociedad fueron las que generaron una justificación de los ataques hacia la población civil, señalándolos tanto de un bando como el otro. No obstante, desde la población se hace un llamado de atención al por qué a pesar de este tipo de cuestionamientos o acusaciones, la Fuerza Pública no hizo las acciones debidas y a tiempo para evitar este tipo de masacres ${ }^{5}$. La estigmatización de la región de los Montes de María fue tan grande que los hijos de los entonces campesinos y trabajadores de la zona iban hasta Barranquilla o Cartagena para sacar su cédula, para que no se supiera que habían nacido en el Carmen de Bolívar o los municipios aledaños (M. Morante, comunicación personal, 5 de diciembre de 2017).

Bajo todo lo que se ha descrito hasta el momento del periodo de violencia y las masacres y víctimas que dejó consigo el conflicto armado en los Montes de María, se puede establecer esta subregión como lo que Taussig denomina como espacio de muerte (Taussig, 2002), ya que se centraliza en lo que el autor nombra una "zona de colonización y también una zona colonizadora [...] el espacio por excelencia para que la incertidumbre y el terror atonten permanentemente, pero también para que revivan y confieran poder con una nueva vida" (Taussig, 2002: 450).

4 http://www.verdadabierta.com/bloques-de-las-farc/5428-las-verdades-de-las-farc-que-exigen-enmontes-de-maria

5 Se debe hacer la salvedad de que con la implementación del Plan Colombia, la política de Seguridad Democrática del Gobierno de Uribe, se buscó la consolidación territorial con la expedición del Decreto No. 2002/2002, que creó zonas de rehabilitación y consolidación para fortalecer la presencia de la Fuerza Pública. 
Tanto las afectaciones de la guerrilla y de las autodefensas ilegales en la región cumplieron una función colonizadora con la que, como lo describe el antropólogo australiano, se mantuvo "la hegemonía o la estabilidad cultural de normas y deseos que facilitan la manera como los gobernantes gobiernan a los gobernados en la tierra de los vivos" (Taussig, 2002: 450). Dicha hegemonía cultural hizo parte del desarraigo y afectación al tejido social, que poco a poco la población está tratando de recuperar por medio de ejercicios de memoria histórica y con la espera de la restitución de sus tierras para no caer de nuevo en otra colonización del discurso político, que tanto ha caracterizado esta región.

\section{Despojo y restitución de tierras}

La región de los Montes de María es un área donde el problema de tenencia de tierras "se ha manifestado siempre de manera violenta, la tierra ha permanecido en constante disputa y ha sido testigo de las más oscuras tragedias" (Cortés, 2011: 80). Aspectos como la restitución $^{6}$, despojo ${ }^{7}$ y abandono ${ }^{8}$ de la tierra son elementos claves que se han desarrollado a lo largo del análisis tanto político como académico para entender este tipo de fenómeno social. Existió un despojo forzado y directo por cuenta de grupos de autodefensas unidas ilegales, al mando de 'Cadena', cabecilla del Bloque Montes de María (Grupo de

6 Entendida como la realización de medidas para el restablecimiento de la situación anterior a las violaciones al Derecho Internacional Humanitario o de violaciones graves y manifiestas a las normas Internacionales de Derechos Humanos, ocurridas con ocasión al conflicto, comprende, entre otras medidas de reparación integral y la devolución de los bienes perdidos (Observatorio de Restitución y Regulación de Derechos de Propiedad Agraria, 2015: 17).

7 La acción por medio de la cual, aprovechándose de la situación de violencia, se priva arbitrariamente a una persona de su propiedad, posesión u ocupación, ya sea de hecho, mediante negocio jurídico, acto administrativo, sentencia, o mediante la comisión de delitos asociados a la situación de violencia (Observatorio de Restitución y Regulación de Derechos de Propiedad Agraria, 2015: 17).

8 La situación temporal o permanente a la que se ve abocada una persona forzada a desplazarse, razón por la cual se ve impedida para ejercer la administración, explotación y contacto directo con los predios que debió desatender en su desplazamiento durante el periodo establecido en el artículo 75 (El periodo establecido en el artículo 75 está comprendido entre el 1 de enero de 1991 y el término de vigencia de la Ley (Ley 1148 de 10 de junio de 2011). (Observatorio de Restitución y Regulación de Derechos de Propiedad Agraria, 2015: 17). 
Memoria Histórica, 2010). Así mismo, en el caso de Montes de María se demostró el nivel de cooptación que tuvieron las autodefensas ilegales en la institucionalidad local y regional.

En 2012, seis notarios y un ex registrador fueron llamados a juicio por la venta irregular de predios que tenían medida de protección especial por ser objeto de despojo (El Tiempo, 2012). Finalmente, la región de Montes de María fue objeto de una gran compra de predios por parte de distintos actores, entre los que se encontraron integrantes del sector empresarial ${ }^{9}$ (Marín et al, 2017: 425). Los procesos de restitución de tierras que adelanta el Gobierno Nacional, en el marco de la Ley 1448 de 2011, se realizan en distintos territorios de la Región Caribe. Para abril de 2016, en los departamentos de la Región Caribe 13701 hectáreas se encontraban con orden judicial de restitución, entre los cuales se destacan los departamentos de Córdoba (4184 hectáreas restituidas), Magdalena (3066 hect.) y Bolívar (2588 hect.) (El Heraldo, 2016).

Como se puede ver en la tabla I-1, el número de solicitudes que se han hecho en todos los municipios que componen los Montes de María es de 7526 realizadas por 5978 personas, desde el 2011 hasta diciembre de 2017, por parte de la Unidad de Restitución de Tierras, siendo Carmen de Bolívar y San Jacinto los municipios que mayor número de solicitudes y personas presentan, y Palmito y Sincelejo los que menos. No obstante, diferentes ONG advierten que solo se han fallado judicialmente 2943 solicitudes de 87118 peticiones de devolución de tierras a nivel nacional, lo que representa apenas el 3,4\% de

9 El Grupo de Memoria Histórica identificó tres tipos de situaciones en donde se dieron estas compras masivas en Montes de María. La primera situación se dio en el marco la imposibilidad por parte de los pobladores de un "retorno digno y seguro", según el cual los campesinos vendieron "voluntariamente", por cuenta de la violencia paramilitar de la región y la propia condición de precariedad en la que se encontraban en medio de la situación de desplazamiento. La segunda situación se dio en el marco de compra de parcelaciones adjudicadas por Incora e Incoder, en donde se realizaron compras y englobes de predios, mediante pagos y/o procesos fraudulentos. En este caso, lo que se dio en Montes de María fue "la compra de múltiples Unidades Agrícolas Familiares, las cuales al estar colindando permiten que se engloben o se constituyan en un solo predio de considerable tamaño". Finalmente, la tercera situación se relacionó con la presión de endeudamiento que los campesinos tenían y las cuales continuaron, no importando la condición de desplazamiento en que se encontraban. Esto produjo una presión que obligó a los campesinos a vender sus predios. Ver: Grupo de Memoria Histórica. La tierra en disputa. Memorias de despojo y resistencia campesina en la Costa Caribe (1960-2010). Bogotá. 2010 
las reclamaciones. "Y si bien es cierto que se han restituido 185024 hectáreas de tierra a 21567 colombianos, el Ejecutivo al presentar la ley había dicho que se debían devolver a sus verdaderos dueños al menos 2 millones 400 mil hectáreas y la meta es hacerlo antes de 2021" (El Heraldo, 2016) ${ }^{10}$.

Tabla I-1: Solicitudes de restitución de tierras por municipio de los Montes de María

\begin{tabular}{|c|c|c|c|c|c|c|c|c|c|}
\hline & & 2011 & 2012 & 2013 & 2014 & 2015 & 2016 & 2017 & Total \\
\hline \multirow{3}{*}{ Carmen de Bolívar } & Solicitudes & 67 & 1248 & 478 & 259 & 75 & 88 & 55 & 2270 \\
\hline & Predios & 54 & 1015 & 330 & 201 & 50 & 69 & 52 & 1771 \\
\hline & Personas & 55 & 1114 & 395 & 206 & 53 & 53 & 46 & 1922 \\
\hline \multirow{3}{*}{ El Guamo } & Solicitudes & 2 & 11 & 17 & 12 & 2 & 8 & 1 & 53 \\
\hline & Predios & 2 & 11 & 7 & 9 & 2 & 6 & 1 & 38 \\
\hline & Personas & 2 & 10 & 6 & 7 & 1 & 4 & 1 & 31 \\
\hline \multirow{3}{*}{ San Jacinto } & Solicitudes & 33 & 640 & 244 & 109 & 48 & 43 & 42 & 1159 \\
\hline & Predios & 28 & 555 & 192 & 64 & 40 & 28 & 41 & 948 \\
\hline & Personas & 31 & 507 & 168 & 69 & 29 & 35 & 35 & 874 \\
\hline \multirow{3}{*}{ María la Baja } & Solicitudes & 8 & 133 & 67 & 105 & 54 & 21 & 20 & 408 \\
\hline & Predios & 7 & 123 & 56 & 85 & 34 & 12 & 18 & 335 \\
\hline & Personas & 8 & 102 & 56 & 81 & 32 & 16 & 16 & 311 \\
\hline \multirow{3}{*}{$\begin{array}{l}\text { San Juan } \\
\text { Nepomuceno }\end{array}$} & Solicitudes & 17 & 173 & 217 & 116 & 36 & 40 & 16 & 615 \\
\hline & Predios & 15 & 144 & 175 & 91 & 34 & 31 & 16 & 506 \\
\hline & Personas & 14 & 146 & 144 & 90 & 28 & 27 & 14 & 463 \\
\hline \multirow{3}{*}{ Zambrano } & Solicitudes & 14 & 103 & 96 & 38 & 34 & 16 & 5 & 306 \\
\hline & Predios & 14 & 93 & 78 & 25 & 24 & 12 & 5 & 251 \\
\hline & Personas & 14 & 87 & 76 & 27 & 26 & 11 & 4 & 245 \\
\hline \multirow{3}{*}{ Córdoba } & Solicitudes & 26 & 91 & 71 & 38 & 28 & 10 & 6 & 270 \\
\hline & Predios & 22 & 81 & 66 & 36 & 24 & 8 & 4 & 241 \\
\hline & Personas & 22 & 80 & 61 & 33 & 22 & 6 & 4 & 228 \\
\hline
\end{tabular}




\begin{tabular}{|c|c|c|c|c|c|c|c|c|c|}
\hline & & 2011 & 2012 & 2013 & 2014 & 2015 & 2016 & 2017 & Total \\
\hline \multirow{3}{*}{ Colosó } & Solicitudes & 5 & 119 & 65 & 16 & 30 & 6 & 6 & 247 \\
\hline & Predios & 4 & 64 & 44 & 14 & 19 & 4 & 6 & 155 \\
\hline & Personas & 5 & 105 & 49 & 10 & 21 & 3 & 6 & 199 \\
\hline \multirow{3}{*}{ Chalán } & Solicitudes & 3 & 28 & 36 & 24 & 49 & 6 & 0 & 146 \\
\hline & Predios & 2 & 15 & 22 & 13 & 17 & 4 & 0 & 73 \\
\hline & Personas & 3 & 26 & 28 & 20 & 36 & 6 & 0 & 119 \\
\hline \multirow{3}{*}{ San Onofre } & Solicitudes & 28 & 122 & 74 & 32 & 38 & 32 & 8 & 334 \\
\hline & Predios & 22 & 106 & 64 & 30 & 21 & 29 & 8 & 280 \\
\hline & Personas & 25 & 87 & 35 & 20 & 32 & 17 & 5 & 221 \\
\hline \multirow{3}{*}{ Los Palmitos } & Solicitudes & 6 & 92 & 26 & 16 & 27 & 1 & 4 & 172 \\
\hline & Predios & 4 & 79 & 21 & 16 & 22 & 1 & 4 & 147 \\
\hline & Personas & 5 & 77 & 19 & 12 & 20 & 1 & 3 & 137 \\
\hline \multirow{3}{*}{ Morroa } & Solicitudes & 109 & 183 & 86 & 64 & 7 & 3 & 0 & 452 \\
\hline & Predios & 76 & 158 & 40 & 46 & 6 & 3 & 0 & 329 \\
\hline & Personas & 88 & 132 & 66 & 46 & 6 & 1 & 0 & 339 \\
\hline \multirow{3}{*}{ Ovejas } & Solicitudes & 38 & 287 & 398 & 96 & 62 & 12 & 19 & 912 \\
\hline & Predios & 26 & 238 & 176 & 61 & 38 & 6 & 17 & 562 \\
\hline & Personas & 32 & 234 & 343 & 59 & 46 & 9 & 16 & 739 \\
\hline \multirow{3}{*}{ Palmito } & Solicitudes & 0 & 2 & 3 & 2 & 1 & 0 & 1 & 9 \\
\hline & Predios & 0 & 1 & 3 & 1 & 1 & 0 & 1 & 7 \\
\hline & Personas & 0 & 2 & 3 & 2 & 1 & 0 & 1 & 9 \\
\hline \multirow{3}{*}{ Tolú Viejo } & Solicitudes & 12 & 26 & 26 & 18 & 25 & 7 & 1 & 115 \\
\hline & Predios & 12 & 24 & 19 & 15 & 25 & 7 & 1 & 103 \\
\hline & Personas & 8 & 21 & 18 & 15 & 22 & 4 & 1 & 89 \\
\hline \multirow{3}{*}{ Sincelejo } & Solicitudes & 6 & 24 & 6 & 6 & 12 & 3 & 1 & 58 \\
\hline & Predios & 5 & 13 & 5 & 6 & 12 & 2 & 1 & 44 \\
\hline & Personas & 5 & 23 & 5 & 5 & 10 & 3 & 1 & 52 \\
\hline
\end{tabular}

Fuente: Unidad de Restitución de Tierras. Fecha de corte: 01/12/2017. 
Esta información es útil para dar cuenta, por un lado, de la problemática que se ha trabajado hasta el momento sobre el impacto social que desplegó el conflicto armado en esta región en específico, y, por el otro, la agudización del empobrecimiento del campesinado montemariano, como resultado del abandono de la actividad productiva, la pérdida de tierra, el acelerado endeudamiento (fruto de las dos anteriores) y la ineficacia de las acciones y políticas diseñadas para el sector rural (Daniels, 2016: 56). La compra masiva de tierras desde 2007 en los Montes de María en las zonas en donde más se vivió el desplazamiento forzado es lo que determina el número de solicitudes frente a esta problemática social y cultural en la región y a lo largo del país.

Tanto el desplazamiento forzado como la restitución de tierras son claras marcas del vacío que ha dejado el conflicto armado en la región en las comunidades cuyo trabajo principal era el cultivo y el trabajo con la tierra. En estos casos, el sufrimiento emocional está significado por la incapacidad de poder trabajar la tierra y de relacionarse con el territorio y las comunidades campesinas, afrocolombianas e indígenas (Radio Macondo, 2016) ${ }^{11}$. Asimismo, el desarraigo, desplazamiento y la violencia que se engendró en ese territorio es lo que ha hecho que la población afrocolombiana de los Montes de María sea una comunidad dispersa y víctima del desplazamiento forzado, así como de su pobreza histórica (El Universal, 2010) ${ }^{12}$.

Frente a este tipo de dinámicas, se pone en juego la legitimidad social del proceso de restitución de tierras que implica la confianza de las víctimas del desplazamiento forzado y despojo de tierras en los Montes de María, ya que a lo largo de los años no se han tenido los resultados esperados y aunque los actores armados ilegales ya no son necesariamente los mismos, sí se tiene en el conocimiento social de la región de que hay grupos armados ilegales que permanecen en el territorio y mantienen las posturas del terror y la violencia. De igual manera, el proceso de restitución de tierras también se ha visto afectado por las actuales dinámicas económicas de siembras de monocultivos en la región como la palma de aceite y la teca, como se va a explicar más adelante. "Existen muchas coincidencias entre el auge

\footnotetext{
11 http://radiomacondo.fm/2016/03/22/desplazamiento-forzado-representa-una-las-formas-perdidasmultiples-mas-crueles/

12 http://www.eluniversal.com.co/sincelejo/local/los-afrocolombianos-dispersos-por-desarraigo
} 
de las plantaciones de palma aceitera y las operaciones paramilitares, el despojo de tierras y compras masivas" (Semana, 2017)13.

\begin{abstract}
Al pisar tierras montemarianas, se hace explícita una de las más grandes problemáticas que afectan en la última década a la región: la siembra de monocultivos (palma aceitera, teca), sus implicaciones y consecuencias se dan en los ámbitos de lo económico, social, cultural y ambiental; en el que los habitantes de la zona se han visto afectados generando mala distribución en la tierra, pobreza en los campos y favoreciendo la violencia. Con el respaldo del Estado a las empresas palmicultoras y terratenientes que siembran teca, los cultivos están presentes en la actualidad en gran parte del territorio entre Bolívar y Sucre. No es gratuito que después de los desplazamientos masivos ejercidos por los grupos armados, empezara el auge de la siembra de la palma aceitera. De esta manera es posible entrever como los grupos armados realizaron la nefasta tarea de arrasar con el territorio y sus habitantes, para que poderosos de la palma entrarán a los territorios sin ninguna restricción. Este panorama fue acompañado de políticas que benefician a los empresarios proponiendo alianzas productivas. (Camacho, 2015: 77)
\end{abstract}

Las señalaciones que hace Camacho sobre los intereses de las grandes industrias palmeras responde precisamente a las coyunturas políticas y sociales de la región en un contexto en el cual las dinámicas y los intereses económicos responden a una serie de hechos violentos contra los pobladores de la región, que hoy en día están luchando por medio de organizaciones sociales y de peticiones judiciales, por su reparación simbólica y restitución de sus derechos.

Desde el 2016, el Ministerio de Cultura ha venido desarrollando un programa llamado "Expedición Sensorial por los Montes de María”, el cual tiene como fin promover la reconstrucción del tejido social y estimular la participación de la comunidad en los procesos culturales de la región, a través de dos líneas de acción: laboratorios

$13 \mathrm{http} / /$ sostenibilidad.semana.com/medio-ambiente/articulo/palma-aceitera-y-su-cultivo-secaa-los-montes-de-maria-en-bolivar/37966 
interdisciplinares de investigación y creación, y el fortalecimiento de los procesos culturales locales, a través de formación en danza y música (MinCultura, 2017). Este modelo de política pública que busca poder asistir a las regiones y los sectores que han sido afectados por el conflicto armado en Colombia es el resultado de las manifestaciones colectivas de la sociedad civil que está en constante búsqueda de recuperarse de los hechos violentos y, al mismo tiempo, de recuperar ese desarraigo cultural que se fue perdiendo por culpa de las dinámicas e imposiciones de la violencia en la región.

\section{Cultura política del Caribe colombiano}

Entender la cultura política de la región de los Montes de María implica entender las dinámicas internas de la región frente a la participación política que se ha generado a lo largo del conflicto armado en ese territorio. Estudios sobre la institucionalidad y las prácticas políticas del Caribe colombiano (Álvarez, 2004; Parada, 2007) muestran cómo desde un enfoque regional las características sociales, económicas, culturales e institucionales pueden afectar el desarrollo de toda una región. En ese sentido, y como lo explica Guerra en su texto, la presencia de la financiación de la actividad política por parte de grupos armados ilegales conlleva nuevos peligros para la práctica democrática en la región Caribe: por un lado, deslegitima la práctica política; y, por otro, la asignación de recursos seguirá generando una mayor distribución desigual del ingreso (Guerra, 2006: 33).

Debido a la fuerte y constante presencia de grupos guerrilleros en la subregión de los Montes de María, los grandes empresarios que habían llegado a la región para invertir en proyectos agroindustriales tuvieron la necesidad de traer con ellos diversos grupos de seguridad privada, algunos de los cuales obtendrían posteriormente amparo legal por medio del Decreto Ley 356 de 1994, y serían denominados en una resolución de la Superintendencia de Vigilancia y Seguridad Privada como servicios de seguridad privada, Convivir (Melamed, 2015: 19).

En el municipio de Zambrano se creó Montesmar como uno de los grupos Convivir que a medida que iba pasando el tiempo se fueron involucrando cada vez más en violaciones sistemáticas a los derechos 
humanos (Grupo de Memoria Histórica, 2011; Melamed, 2015), y debido a la expansión de las autodefensas ilegales en el norte del país a mediados de la década de los noventa, y al alto valor estratégico, se fue consolidando la región de los Montes de María como un escenario de confrontación por el control territorial entre las guerrillas de las FARC, ELN, ERP, el bloque Norte de las Autodefensas Campesinas de Córdoba y Urabá (ACCU), luego denominado Bloque Héroes de los Montes de María, y la Fuerza Pública.

Fue así como, poco a poco, en la región de los Montes de María las autodefensas ilegales cometieron 42 masacres entre 1996 y 2003, dentro de las que se destacan las ejecutadas en los municipios y corregimientos de Pichilín (1996), Macayepo (2000), El Salado (2000), Mampuján (2000), Ovejas (2000), Colosó (2000) y Chengue (2001). En ese mismo período, 30677 personas fueron víctimas de desplazamiento en la región, y, como resultado de su accionar, tras su desmovilización en 2005, el Bloque Héroes de Montes de María tiene registradas 6686 víctimas en la Unidad de Justicia y Paz (Grupo de Memoria Histórica, 2011: 76).

[...] durante su despliegue operativo en la región, el bloque Héroes de los Montes de María convertiría la zona en una de las regiones del país con mayor número de violaciones a los derechos humanos en el territorio colombiano, y sus acciones incluirían las masacres de El Salado y Macayepo, en el Carmen de Bolívar, Chengue, en el municipio de Ovejas, y la de Las Brisas en María la Baja, contando con el apoyo de funcionarios públicos, influyentes personalidades políticas regionales y, en ocasiones, con la complicidad de miembros de la fuerza pública. La gran espiral de violencia generada en la región por las fuerzas paramilitares se dirigió a combatientes de organizaciones subversivas, miembros de la sociedad civil y fuerzas políticas de oposición a los gamonales asociados con el paramilitarismo. Esta alianza macabra tendría objetivos económicos, políticos, electorales y criminales, tal como lo prueban las sentencias condenatorias que la Corte Suprema de Justicia ha impartido en contra de personalidades políticas con influencias en la región de los Montes de María, entre quienes están, entre algunos, el representante a la Cámara, ex gobernador de Sucre y primer congresista 
condenado por la Corte Suprema de Justicia por el denominado fenómeno de la "parapolítica", y quien fuera encontrado penalmente responsable por los delitos de concierto para delinquir agravado. Igualmente emblemática es la condena a cuarenta años de prisión que la Sala Penal de la Corte dictó en contra del ex senador Álvaro García, al encontrarlo penalmente responsable por los delitos de peculado, concierto para delinquir agravado y como autor intelectual de la masacre de Macayepo, en la que fuerzas paramilitares asesinaron a quince campesinos en el año 2000. (Melamed, 2015: 20)

El fenómeno de la parapolítica en la región de los Montes de María, y en general en la Costa Caribe colombiana, tiene como principal característica la fuerte influencia que ejerció la íntima relación entre las autodefensas ilegales y la "ilegalidad con las altas esferas del poder político y económico", como lo señala Melamed en su investigación. Esta compleja relación política que se ha vivido en la región ha tenido como consecuencia que la población pierda la credibilidad en posibles políticas de desarrollo para los municipios, en donde los problemas tuvieron un fuerte impacto social por el despojo de tierras y el desplazamiento forzado que generó el conflicto armado interno.

Las condenas que se han proferido hasta la fecha de los personajes de la política regional como gobernadores, congresistas y senadores, entre otros, por sus vínculos con la parapolítica, dan cuenta de que las élites políticas regionales, "en su afán de resistir a los cambios democráticos en el nivel nacional y a los intentos de negociación con las guerrillas, también tienen necesidad de apoyarse en el actor armado ilegal, muestran la clara intención de buscar ese respaldo y están dispuestas a responder a algunas exigencias de los paramilitares" (Romero, 2007: 12). Los beneficios políticos, económicos y electorales que se tenían por ambas partes, autodefensas unidas ilegales y políticos de la región, resaltan una vez más que el control territorial por el que se luchaba en los Montes de María tenía como fin mantener unas dinámicas propias de la violencia para controlar las rutas del narcotráfico desde el interior del país hacia el Golfo de Morrosquillo.

Es producto de alianzas electorales y políticas de mutuo beneficio entre una organización criminal y narcotraficante y políticos que, se supone, representaban la legalidad y el 
Estado. La parapolítica es una alianza del narcotráfico, criminales organizados y elites políticas y económicas para tomarse el poder y la representación política. El problema de la parapolítica no es que se firmaran pactos para "refundar el Estado"; el problema es que esos pactos no fueron palabras al viento, sino un propósito logrado por medio de la combinación de violencia, narcotráfico y política. (PODEC, 2011: 35)

El interés estratégico que esta zona representa se mantiene intacto, y “la voracidad de las prácticas clientelistas antidemocráticas y violentas representa un peligro inminente para el funcionamiento adecuado de las instituciones democráticas por parte de quienes aspiran a controlar los diversos entes territoriales de la zona" (Melamed, 2015: 22), razón por la cual la participación política a la que tiene derecho la sociedad se ha visto desarticulada y afectada por una estructura de la violencia por parte de las mafias y la corrupción. Las investigaciones que se han hecho sobre esta problemática de la parapolítica han dado cuenta de que en muchas de las ocasiones fue la élite política de la región quien buscó la colaboración y participación de las autodefensas unidas ilegales para dar cumplimiento a su interés político y económico.

\section{El abandono estatal en la región para la solución del conflicto}

Gracias a las diversas salidas de campo en los Montes de María, se pudo observar que hay una percepción generalizada de que parte del conflicto que se vivió en la subregión fue debido a la ausencia del Estado, lo que generó un aumento de capacidad de los grupos armados ilegales como los frentes 35 y 37 de las FARC y las Autodefensas. Este tipo de presencia de las guerrillas y las autodefensas ilegales impuso un control territorial en la región de los Montes de María. El establecimiento de rutas del narcotráfico del centro del país hacia el golfo de Morrosquillo permitió que los grupos guerrilleros que se encontraban en la región se dedicaran al narcotráfico y a la extorsión de la población.

En la actualidad, esto suena como si no fuera verdad, pone en tela de juicio la labor de la Armada Nacional (Castiblanco et al., 2017); debería ser una afirmación. Fue gracias al apoyo de la Fuerza Pública 
que se pudo repeler a los grupos armados ilegales y que desde las alcaldías locales se están planteando proyectos de infraestructura, empleo y recuperación del campo para recuperar las actividades agrícolas. Incluso se propone que los Montes de María es una región autosuficiente tanto por la producción agrícola que se está dando en los diferentes municipios que la componen, como por el índice de empleo que tiene la región. Frente a estas declaraciones del Secretario de Gobierno del Carmen de Bolívar, cabe resaltar que según datos del Censo del 2005 (DANE, 2005) y los diagnósticos que hace el PODEC (2011):

En el Carmen de Bolívar el 5,8\% de los trabajadores tiene un negocio familiar, el 7,7\% vende por su propia cuenta, el 2,6\% hace algún producto para vender, el 19,6\% ayuda en el campo o en la cría de animales, el 55,8\% hace otros oficios de hogar y el 9,2\% hace otro tipo de actividad. En San Jacinto el 7,8\% tiene un negocio familiar, el 8,9\% vende por su propia cuenta, el 8,1\% hace algún producto para vender, el 7,6\% ayuda en el campo o en la cría de animales, el 55,8\% hace otros oficios de hogar y el 11,7\% hace otro tipo de actividad. En Ovejas el 7,5\% tiene un negocio familiar, el $4 \%$ vende por su propia cuenta, el 5,9\% hace algún producto para vender, el 22,2\% ayuda en el campo o en la cría de animales, el 47,3\% hace otros oficios de hogar y el 13,1\% hace otro tipo de actividad. En San Onofre el 7,2\% tiene un negocio familiar, el 5,7\% vende por su propia cuenta, el 1,8\% hace algún producto para vender, el 7,8\% ayuda en el campo o en la cría de animales, el 67,3\% hace otros oficios de hogar y el 10,2\% hace otro tipo de actividad. (PODEC, 2011: 20)

No obstante, se debe entender desde un punto de vista más crítico por qué se generó dicha ausencia estatal que no solo hace parte del imaginario colectivo de los pobladores de la región, sino que también se ha explicado como una de las grandes causas del conflicto armado interno de los Montes de María. Esta región tiene la particularidad de hacer parte de dos departamentos con un modelo consolidado de desarrollo económico, con un poder político importante y participación en la creación de los diferentes planes de desarrollo de los gobiernos de turno. 
Vale la pena aclarar que en el momento de la consolidación de los grupos ilegales el Gobierno tenía problemas internos, sufrido por los escándalos de inclusión de dineros del narcotráfico en la campaña presidencial en el periodo del 1994 al 1998, causando una mala imagen internacional que propició traumatismos en las relaciones comerciales y políticas con los países de la región. Estos motivos se iniciaron en el abandono de estos municipios, y esta indiferencia por la prioridad en otros aspectos de la estabilidad del Gobierno causó una consolidación de los grupos armados ilegales sobre la base de sus promesas de seguridad y mejoramiento en las relaciones sociales y económicas aprovechando la vacancia estatal.

Estas razones de interés prioritario para el gobierno Samper, en el que la estabilidad económica y social estaban en peligro por las represiones tomadas por gobiernos internacionales aliadas al país, dejaron de lado las pretensiones para formalizar un proceso de paz necesario por el conocimiento del Gobierno de las acciones armadas de grupos guerrilleros y autodefensa unidas ilegales. El gobierno de Ernesto Samper escogió la peor táctica imaginable para afrontar este asunto paramilitar: ni los combatió, ni los reconoció; los trató como delincuentes, pero les prometió un asiento en una negociación futura (El Tiempo, 1998).

Había una estrategia de combinar formas legales e ilegales de participación política, para el acceso al poder local y regional, en los que las autodefensas ilegales cumplieron con la función coactiva e intimidatoria para obligar a la población a votar por determinados candidatos producto de los acuerdos entre las élites y los jefes paramilitares (Usaid, 2016). Estas acciones causaron miedo en la población y desconfianza por parte de la población civil, puesto que las élites tenían control sobre las instituciones y las acciones implementadas en los territorios; por esta razón, las posibles soluciones dadas desde el Gobierno central no generaban los resultados deseados, y las organizaciones como la ANUC eran las únicas denunciantes sobre este fenómeno en donde los recursos públicos eran utilizados con intereses personales; pero estas alianzas de grupos armados ilegales y las élites políticas comenzaron a amenazar y asesinar a los líderes de la defensa de los recursos para recuperar la región; esta ley del silencio mantuvo la región en el abandono.

La única entidad estatal recordada dentro de los municipios de la región es el Incora y su lucha junto a las organizaciones campesinas 
para el debido aprovechamiento de la tierra y su producción. Los objetivos de la institución se vieron empañados por las acciones de los grupos ilegales, que no permitiendo la adecuada distribución y producción en cada uno de los campos de la región, con lo cual conseguían tierras a bajos precios por el temor de los dueños por su vida y estos repartían estas tierras a campesinos que posteriormente quebraban por no tener la opción de cultivar; esto resultaba en una titulación de tierras para un cumplimiento de metas pero no se realizó un seguimiento sobre lo que pasaba en estas tierras y quiénes finalmente eran los dueños.

Años más tarde, con el gobierno de Andrés Pastrana se realizaron los primeros acercamientos de un proceso de paz que prometía ser la solución para la desmovilización de estos grupos armados ilegales, pero las pretensiones no fueron suficientes para ninguna de las partes y por tal motivo la mesa de negociación no tuvo continuidad y esto rompió totalmente las relaciones entre el Gobierno y estos grupos, y los brotes de violencia y el control armado en la región continuaron.

\section{La Armada Nacional en los Montes de María: una intervención para el fortalecimiento económico y social de la región}

Teniendo en cuenta las masacres, violaciones y demás brotes de violencia, desde el Gobierno central se intensifican varias políticas para la recuperación de la región, y entre los objetivos primordiales se encontraba tener el control político y armado de la región por parte del Gobierno y en este punto llega la seguridad democrática, específicamente la recuperación de la soberanía territorial en la región, que significó la entrada en operación de cuatro Brigadas, tres de ellas del Ejército Nacional y una de la Armada Nacional (Daniels, 2011: 15).

Frente a este contexto de los Montes de María, la seguridad de una región agrícola y ganadera de tradición se encontraba vulnerable debido a las acciones violentas de los diversos grupos armados ilegales, lo cual fue un punto de foco para el Estado colombiano y por este motivo se le encargaron a las fuerzas militares tomar las medidas necesarias para retomar el control armado y político de la región. El Ejército Nacional no tenía suficiente capacidad en sus tropas para 
abarcar todo el territorio, como lo señaló el General Colón (r), ya que los límites de acción estaban definidos previamente y la tropa más cercana era la I División, la cual llegaba hasta Magangué (R., Colón, comunicación personal, 11 de enero de 2018). Por este motivo, la Armada Nacional tomó la decisión de apoyar la orden emitida por el Jefe de Estado, pensando en el bienestar de la comunidad que sufría cada uno de los ataques de estos grupos, amplió su misión de la defensa de los espacios marítimos y fluviales, para participar en la protección de la población en el espacio terrestre.

El logro de la Armada Nacional no fue fácil, la consolidación dela Fuerza Armada a finales de la década de los ochenta se dio como resultado de la unión del Gobierno, la Fuerza Pública y la población civil. Esta acción conjunta trajo consigo la adquisición de la primera finca en Corozal para la instalación del batallón respectivo; un batallón en Malagana; y la transformación de la fuerza anfibia del Atlántico en la Brigada de Infantería de Marina. A partir de su conformación, la Brigada de Infantería de Marina No. 1 comenzó con trabajos de inteligencia y logística, las acciones militares realizadas empezaron a dar resultados con la desmovilización de grupos armados ilegales reconocidos, pero aún faltaba mucho trabajo por realizar, ya que los otros grupos armados ilegales se estaban fortaleciendo en cantidad de hombres y acciones contra la población civil para imponer su autoridad en los municipios de la región.

Es así como a finales de los noventa el Gobierno y la Armada Nacional evidenciaron el fortalecimiento de estos grupos armados ilegales en la toma del control de los municipios en aspectos económicos y políticos. Por este motivo, se destina un mayor presupuesto para la Brigada de Infantería de Marina No.1 para la compra de armamentos, equipos y aumentar el número de hombres de la Infantería de Marina No. 1 con el fin de dar cobertura a toda la región (A. Hernández, comunicación personal, 2 de diciembre de 2017). Posterior al año 2000, con las acciones del Gobierno y las políticas de seguridad implementadas, se termina de consolidar la Brigada de Infantería de Marina con el objetivo de retomar el control armado y retornar la tranquilidad de la región y la confianza de la población en las instituciones. "En este contexto, ya existían muchos cambios en el territorio como por ejemplo el abandono de tierras, la cantidad de terrenos selváticos, la gran cantidad de tierras deforestadas, vías destruidas; y en el aspecto armado, y el aumento de los hombres enemigos a combatir por parte 
de la Armada Nacional" (A. Hernández, comunicación personal, 2 de diciembre de 2017).

La Infantería de Marina, por medio de sus acertadas estrategias militares y acciones determinadas para debilitar estos grupos armados ilegales, comenzó a obtener resultados reduciendo la cantidad de ataques a la población civil. Esto fue reconocido por la población civil de la región, la cual fue cambiando la manera de relacionarse con la Fuerza Pública, por lo que esto implicaba durante el auge de la violencia y presencia de grupos guerrilleros y autodefensas unidas ilegales en la región. Al evidenciar los grandes avances en la seguridad, gran parte de la población comenzó a denunciar y a entregar información sobre los integrantes de los grupos armados ilegales, dando testimonio de sus acciones y de su ubicación, en los espacios que generó la Armada Nacional por medio de llamados a la población por perifoneo, posibilitando así la participación ciudadana en las estrategias para capturar a los líderes de estos grupos y debilitar su poder, logrando de esta manera la desmovilización de los grupos armados ilegales a causa de las operaciones militares que neutralizaron a los líderes y a sus principales responsables.

Para lograr estos objetivos fue fundamental la creación de la Casa del Almirante, este lugar nació en San Jacinto, Bolívar, en el año 2003 con unos objetivos claros: en primer lugar, como estrategia para contrarrestar el conflicto, con la presencia permanente de la Armada Nacional en el territorio y base central de la planeación de la seguridad en la jurisdicción con la presencia del Almirante Guillermo Barrera Comandante de la Fuerza Naval del Caribe, quien trasladó su oficina de Cartagena para instalarse en los Montes de María (R. Colón, comunicación personal, 11 de enero de 2018); en segundo lugar, un espacio familiar para la comunidad en donde podían compartir con total tranquilidad la información importante sobre los movimientos de los grupos armados ilegales, esto causó el empoderamiento de la población para enfrentar el conflicto y la recuperación de la confianza en las Fuerzas Militares para su protección (G. Godín, comunicación personal, 6 de febrero de 2018).

Para el mes de mayo de 2008, se logró la disminución en un 90\% de la estructura armada de los frentes 35 y 37 de las FARC, la reducción en un 95\% de la estructura armada del ELN y la desmovilización total del ERP. Se desarrolló específicamente en el área de las aguacateras Norte y Sur, Aromeras Norte y Sur, sectores de retaguardia 
estratégica de las FARC (Diálogo, 2010). A partir de la recuperación de la seguridad en la región, la Armada Nacional comenzó a contribuir con la reconstrucción de un tejido social para toda la población, cambiando la mentalidad de la población, pasando del miedo a la esperanza, de la guerra a la paz, de la desconfianza al empoderamiento en reconocer la importancia de cada uno de los habitantes en construir una nueva región. El tejido social comenzó con el retorno de los campesinos desplazados por la violencia. De acuerdo con los datos de la Armada Nacional, a El Salado han regresado más de tres mil desplazados y otros tres mil volvieron a Macayepo, poblaciones fuertemente golpeadas por las masacres más dolorosas de la historia de nuestro país (Caracol Radio, 2011).

La Armada Nacional intensificó la labor de desminado por toda la región a través de la Agrupación de Explosión y Desminado de la Infantería de Marina, realizando un desminado manual y mecánico, logrando el desminado total de áreas como el corregimiento de Bajo Grande (San Jacinto-Bolívar), Capacá (Zambrano- Bolívar) y El Salado (El Carmen de Bolívar), donde fueron entregados 12000,18500 y 25000 metros cuadrados de tierra libres de minas respectivamente (Castro, 2012). Todo esto tiene el objetivo principal de que los campesinos retomen las labores agrícolas de manera tranquila para desarrollar las actividades a las cuales se dedicaban antes del conflicto; una función de importancia para retomar los niveles productivos necesarios para el sostenimiento de tantas familias con esperanzas en la región.

En el aspecto económico, la Armada Nacional, garantizando la seguridad de la región y las tierras libres de grupos armados y de minas, permitió el aumento de la producción del sector agrícola y ganadero; de esta manera se aprovechó la ventaja competitiva que tiene la región por su ubicación geográfica y bondades en sus cultivos ante el mercado nacional e internacional. Uno de los productos beneficiados es el aguacate, el cual tuvo un crecimiento vertiginoso de producción llegando a comercializar 100500 millones de pesos en el año 2010, según la Asociación de Productores de Aguacate de la región (Diálogo, 2010). Este resultado también se debe a la acción de ingenieros militares pertenecientes al Ejército Nacional y la Infantería de Marina, el cual construyó la transversal de los Montes de María, carretera que comunica al Carmen de Bolívar con Macayepo, por donde los campesinos llevan el aguacate hacia la carretera central para llevarlo a los centros de comercio. Esto demuestra el compromiso permanente 
con la región por parte de la Armada Nacional con la infraestructura para contribuir al desarrollo regional.

La gobernabilidad es un punto importante para la Armada Nacional y la Infantería de Marina, que, con sus conocimientos y grandes esfuerzos realizados por la región, tienen injerencia en la planeación junto con las autoridades locales y la población para garantizar mejores condiciones de calidad de vida para los habitantes que necesitan para construir sus vidas, posterior al conflicto. A parte de las labores anteriormente nombradas, la confianza en la Armada Nacional por parte de la región se mantiene por su presencia permanente en cada uno de los municipios en las Casas del Almirante, sitio con las puertas abiertas para las personas en donde pueden expresar sus ideas y proyectos para el beneficio de la comunidad, siendo la Armada Nacional un canal de comunicación entre la comunidad y las instituciones respectivas, muestra de esto existen actualmente la Casa del Almirante en San Jacinto, Carmen de Bolívar, San Onofre, San Bernardo y Toluviejo.

La Armada Nacional, con el propósito de consolidar el tejido social en la región, ha tenido grandes aliados estratégicos para la reconstrucción de una población golpeada por el conflicto. Una herramienta de importancia para la divulgación de las acciones en beneficio de la seguridad y mejorar la calidad de vida de los habitantes se representa en la emisora de la Armada Nacional llamada Marina Estéreo, esta emisora es compañía permanente de los habitantes donde informan las noticias más importantes de la región de interés prioritarioy, por otro lado, es un medio para convocar a diferentes actores sociales, como por ejemplo la población civil, para que asistan y participen en los proyectos productivos y de interés social de distintas entidades; $y$ convocar a las entidades públicas y privadas para lograr patrocinios para llevar a cabo actividades que permitan mejorar la calidad de vida.

$\mathrm{El}$ apoyo de los entes gubernamentales, eclesiásticos, organizaciones no gubernamentales, fundaciones y la empresa privada, es fundamental para la inclusión de la población mediante un programa de Acción Integral que potencializa proyectos y jornadas que propenden por el desarrollo social y económico, beneficiando a toda la comunidad desde la educación, la cultura, el folclor y el fortalecimiento de los principios y valores de los habitantes de la región de los Montes de María (Armada Nacional de Colombia, 2013). Todo esto, logrado a través de la Casa del Almirante, en donde se realizan 
reuniones constantes con el fin de ejecutar asesorías, proyectos de infraestructura, planes productivos, brigadas médicas, alianzas con entidades privadas para la construcción de viviendas para las víctimas del conflicto, en donde la Armada Nacional aporta la mano de obra y jornadas de apoyo al desarrollo en la región destacándose en este último el grupo GEOS, liderado por infantes de marina llevando a cabo varias actividades con los niños, jóvenes y padres de familia en recreación (G. Godín, comunicación personal, 6 de febrero de 2018).

El desarrollo social de la Armada Nacional se complementa con los Consejos de Seguridad permanente con los habitantes de cada una de las veredas que componen la región y estar al tanto de cada uno de los riesgos posibles a la tranquilidad de la población. Este desarrollova acompañado de obras como es el caso de la Compañía de Acción Integral de la Armada Nacional, la cual viene desarrollando los trabajos de construcción, adecuación y mantenimiento de obras de infraestructura en el corregimiento de Flor del Monte en el municipio de Ovejas, donde se entregó un nuevo acueducto y un cementerio en apoyo con la Alcaldía de este municipio, con el firme propósito de reafirmar el proceso de consolidación de las poblaciones de los Montes de María. Otras obras a destacar es la reconstrucción del estadio de fútbol de San Bernardo del Viento en Córdoba en 2011, un puesto de salud en Santiago de Tolú en 2012 y la entrega de una iglesia a la comunidad de Don Gabriel, Sucre (Armada, 2013).

Estas acciones demuestran la importancia de la Armada Nacional en la reconstrucción de una región con grandes capacidades productivas, una población que retomó la esperanza y la confianza en su función para contribuir al desarrollo de la región. Este compromiso social de la Armada Nacional contribuye a la región para tener el reconocimiento como zona de paz y un ejemplo mundial del proceso de un territorio en el postconflicto; esto resulta en el mejoramiento de la gobernabilidad, seguridad, actividades económicas y en la confianza de actores externos que vuelvan a creer en esta región capaz de abrir sus puertas a la industria, inversiones extranjeras para abrir nuevos caminos de empleo para la población y potencializar el turismo para aprovechar los hermosos paisajes y la riqueza histórica que compone cada rincón de los Montes de María.

Por último, cabe señalar que el control político y militar que impulsó el Gobierno a partir de 2001 permitió abrir la conciencia social de los habitantes y creer en una región con grandes capacidades 
para el progreso de los mismos con apoyo del Gobierno a través de la creación de programas focalizados en desarrollo y paz, los cuales generaron confianza en las grandes multinacionales para enfocar sus esfuerzos en la productividad del territorio y mejorar la calidad de vida de los habitantes.

Los pobladores de la región tienen un fuerte arraigo por su región y la mayoría desea quedarse en sus municipios, esto se representa en la cantidad de asociaciones de todas índoles productivas y sociales. Con respecto a las asociaciones productivas, requieren de apoyo de las entidades nacionales en toda la cadena productiva y en la comercialización para aumentar las ganancias de los productores, en el cultivo para estar al nivel de la exigencia del mercado y del adecuado aprovechamiento de la tierra. Pero, como se ha venido argumentando, las asociaciones son creadas por alguna situación de proyectos asistenciales que terminan con objetivos de corto plazo, dejando a la deriva la población sin ventajas comparativas y empoderamiento (F. Blanco, comunicación personal, 11 de diciembre de 2017).

Esta región puede ser un ejemplo a nivel mundial de reconstrucción de la paz, pero requiere de acciones claras, constantes y contundentes no solo por un presupuesto, sino que requiere de un compromiso claro y verdadero para consolidar procesos de desarrollo regional que incluyan a toda la población que está en constante construcción identitaria para reformar y reconfigurar el tejido social que se fue perdiendo a lo largo del conflicto armado, y que poco a poco se va reforzando gracias al esfuerzo de los pobladores que se han atrevido a regresar a su tierra natal para construir la paz y estabilidad que la historia tanto le debe a esta subregión del país.

\section{Referencias}

Abello Vives, A. (1997). La región y la economía mundial: seis ensayos de economía política sobre el Caribe colombiano en los tiempos de la globalización. Bogotá: Ediciones Cedetrabajo.

Aguilera Díaz, M. (2013). Montes de María: una subregión de economía campesina y empresarial. Cartagena: Banrep.

Álvarez Llanos, J. (2004). Prácticas políticas en el Caribe colombiano a principios del siglo Xx. En: Universidad Del Atlántico, Historia Caribe, Barranquilla (Col), No. 9. 
Armada Nacional de Colombia. (Enero de 2013). La Casa del Almirante de San Jacinto. Un Compromiso con los Montes de María. AlaMar. p. 16.

Blanco Romero, W. (2009). Historia de El Carmen de Bolivar y su tabaco en los Montes de María. Siglos XVIII-XX. Cartagena: Universidad de Cartagena.

Blanco Romero, W. (2011). Tabaco, economía campesina y capitalismo en los Montes de María, 1850-1930. En: El Taller de la Historia, III(3):191201. ISSN: $1657-3633$.

Camacho Rojas, T. (2015). Aportes para la protección del territorio en Montes de María desde un enfoque pedagógico e intercultural. Trabajo de grado para optar el título de Licenciatura en Educación Comunitaria con Énfasis en Derechos Humanos. Universidad Pedagógica Nacional. Bogotá.

Caracol Radio. (11 de septiembre de 2011). Caracol Radio. Obtenido de http:// caracol.com.co/radio/2011/09/11/nacional/1315742400_545502.html

Castiblanco Durán, Camilo. (2017). Protegiendo el Azul, comprendí el rojo de la bandera: narrativas desde la Armada. Camilo Andrés Castiblanco Durán, Mateo Echeverry Ángel, Doris Yaneth Herrera Monsalve, Carol Malaver Sánchez. Bogotá. Universidad Santo Tomás.

Castro, J. (4 de abril de 2012). Desminadas 3 áreas en los Montes de María. El Universal.

Correa, N. R. (s.f.). Corozal-Bolívar: un pueblo patriota en las Sabanas Corozal y su sacerdote en 1812. Historias Locales. Bogotá: Ministerio de Educación Nacional.

CEDEC. Centro de Estudios para el Desarrollo y la Competitividad (2012). Informe Económico de los municipios de la Jurisdicción dela Cámara de Comercio de Cartagena. Cartagena de Indias.

Centro Nacional de Memoria Histórica (2017). Campesinos de tierra y agua: memorias sobre sujeto colectivo, trayectoria organizativa, daño y expectativas de reparación colectiva en la región Caribe 1960-2015. Campesinado en el departamento de Sucre, CNMH, Bogotá.

Cortés Reyes, O. (2011). El resto de la consolidación en Montes de María: la aplicación de la seguridad democrática a nivel nacional. Bogotá: Pontificia Universidad Javeriana. 
DANE (2005). Pueblos indígenas. Disponible en la https://www.dnp.gov. co/programas/desarrollo-territorial/Paginas/pueblos-indigenas. aspx

Daniels Puello, A. y Múnera Cavadía, A. (2011).Los Montes de María:región, conflicto armado y desarrollo productivo. Instituto Internacional de Estudios del Caribe. Cartagena de Indias, Colombia: Pluma de Mompox S.A.

Daniels, A. (2016). La transformación de la estructura productiva de los Montes de María: de despensa agrícola a distrito minero-energético. Memorias Revista Digital de Arqueología e Historia desde el Caribe. $N^{\circ} 29,52-83$.

Diálogo. (2010). Desempeño militar en la consolidación colombiana. Diálogo.

El Heraldo (2016). Así va la restitución de tierras en el Caribe. 18 de abril de 2016.

El Universal (2010). Los afrocolombianos, dispersos por desarraigo. $11 \mathrm{de}$ mayo de 2010.

El Universal (2010). Compañía está ilíquida para comprar producción de tabaco. 11 de noviembre de 2010.

Finagro (Fondo para el Financiamiento del Sector Agropecuario). 2014. Perspectiva del sector agropecuario Colombiano. Preparado por el Equipo Técnico de Presidencia. Bogotá.

Fundación Semana. (2015). Los conflictos de la paz. Bogotá: Semana.

Grupo de Memoria Histórica (2009). La masacre de El Salado. Esa guerra no era nuestra. Bogotá: Taurus y Fundación Semana.

Grupo de Memoria Histórica (2010). La tierra en disputa. Memorias del despojo y resistencias campesinas en la Costa Caribe (1960-2010). Bogotá: Taurus y Fundación Semana.

Grupo de Memoria Histórica (2011). Mujeres y guerra. Víctimas y resistentes en el Caribe colombiano. Bogotá: Taurus y Fundación Semana.

Guerra Curvelo, W.(2006). Cultura, instituciones y desarrollo en el Caribe colombiano. Elementos para un debate abierto. Observatorio del Caribe Colombiano Cartagena, 1 de septiembre de 2006.

Ley 1148 de 2011. Por la cual se dictan medidas de atención, asistencia y reparación integral a las víctimas del conflicto armado interno y se dictan otras disposiciones. Congreso de la República (2011).

López Macías, F. J. y Castrillón, P. (2007). “Evolución y desarrollo de la agroindustria en Colombia”. En: Colombia Asuntos Económicos y 
Administrativos. Centro de publicaciones Universidad de Manizales v.12 fasc. pp. 9-35.

Marcha Patriótica (2017). La concentración de la tierra en los Montes de María frente a los acuerdos de La Habana. 20 de diciembre de 2017. Marín et al. (2017). Victorias desde el aire: la Fuerza Aérea Colombiana y el término del conflicto armado. Segunda edición. Bogotá: Grupo Editorial Ibáñez.

Melamed,J.D. (2015). Montes de María: bastión estratégico de la ilegalidad. En: Elecciones regionales y locales, crimen y política en el Caribe colombiano. Pp. 19-23. Friedrich-Ebert-Stiftung. Bogotá.

Menco, D. (2012). El desarrollo económico local y bienestar social en los Montes de María. Observatorio de la Economía Latinoamericana. Morante, M. (2016). El Carmerazo. Cartagena de Indias.

Jimeno, M. (2005). Caribe Colombia. Cartagena: Banco de la República. Observatorio del Programa Presidencial de Derechos Humanos y Derecho Internacional Humanitario. 2003. Panorama actual de la región de Montes de María y su entorno. ISSN 1657-818 X Serie Geográfica No. 19. Bogotá.

Parada Corrales, J.(2007).Laeconomía políticadelasinstituciones enel Caribe colombiano. Ensayo presentado al Taller del Caribe Colombiano: Políticas para reducir las desigualdades regionales en Colombia.-Barranquilla. Mayo 16 del 2007. Disponible en: https://www.uninorte. edu.co/documents/228749/5e58eaf9-62e5-47c6-a4e2-741aocddeoo8

PNUD Colombia. (2010). Los Montes de María: análisis de la conflictividad. Colombia: Impresol.

PODEC (Plataforma de Organizaciones de Desarrollo Europeas en Colombia). (2011). Análisis del Plan de Consolidación de Montes de María: una mirada desde el desarrollo, la democracia, los derechos humanos y la cooperación internacional. Bogotá.

Radio Macondo (2016). El desplazamiento forzado representa una de las formas de pérdidas múltiples más crueles. 22 de marzo de 2016.

Reyes Posada, A., L, Duica Amaya y W.A. Pedraza (2010). El despojo de tierras por paramilitares en Colombia. Mimeo. Bogotá.

Ríos Moscote, C. A. (2015). El tabaco y la valorización de la tierra en la provincia de El Carmen, 1859-1875. Universidad de Cartagena Facultad de Ciencias Humanas Programa de Historia. Cartagena de Indias.

Romero, M. (2007). Parapolítica: la ruta de la expansión paramilitar y los acuerdos políticos. Bogotá: Cerec, Corporación Nuevo Arco Iris. 
Semana (2017). El cultivo de palma aceitera seca a los Montes de María. o6 de junio de 2017.

Serje, M. (et ál.) (2010). Desarrollo y conflicto: territorios, recursos y pasajes en la historia oculta de proyectos y políticas. Universidad de los Andes, Facultad de Ciencias Sociales, Departamento de Antropología, CEso, Ediciones Uniandes. Bogotá.

Taussig, M. 2002 [1987]. Chamanismo, colonialismo y el hombre salvaje. Un estudio sobre el terror y la curación. Bogotá. Norma.

USAID. (2016). La pelona, memoria de luchas y vivencias colectivas. La aldea que construyó su sabana de sueños. Sincelejo: Cecar.

Verdad Abierta (2014). Las verdades de las FARC que exigen en Montes de María. 2 de septiembre de 2014.

Viloria de la Hoz, J. (1999). Tabaco del Carmen: producción y exportación de tabaco en los Montes de María 1848- 1893. Cuadernos de Historia Económica y Empresarial No. 3, Cartagena: Banco de la República. 